Trinity University

Digital Commons @ Trinity

8-2003

\title{
Lithofacies Control in Detrital Zircon Provenance Studies: Insights from the Cretaceous Methow Basin, Southern Canadian Cordillera
}

Kathleen D. Surpless

Trinity University, ksurples@trinity.edu

J. B. Mahoney

J. L. Wooden

M. O. McWilliams

Follow this and additional works at: https://digitalcommons.trinity.edu/geo_faculty

Part of the Earth Sciences Commons

\section{Repository Citation}

DeGraaff-Surpless, K., Mahoney, J. B., Wooden, J. L., \& McWilliams, M. O. (2003). Lithofacies control in detrital zircon provenance studies: Insights from the Cretaceous Methow basin, southern Canadian Cordillera. Geological Society of America Bulletin, 115(8), 899-915. doi: 10.1130/B25267.1

This Article is brought to you for free and open access by the Geosciences Department at Digital Commons @ Trinity. It has been accepted for inclusion in Geosciences Faculty Research by an authorized administrator of Digital Commons@ Trinity. For more information, please contact jcostanz@trinity.edu. 


\title{
Lithofacies control in detrital zircon provenance studies: Insights from the Cretaceous Methow basin, southern Canadian Cordillera
}

\author{
Kathleen DeGraaff-Surpless ${ }^{\dagger}$ \\ Geological and Environmental Sciences, Stanford University, Stanford, California 94305-2115, USA
}

J. Brian Mahoney
Department of Geology, University of Wisconsin, Eau Claire, Wisconsin 54702, USA

Joseph L. Wooden

U.S. Geological Survey, Menlo Park, California 94025, USA

Michael O. McWilliams

Geological and Environmental Sciences, Stanford University, Stanford, California 94305-2115, USA

\section{ABSTRACT}

High-frequency sampling for detrital zircon analysis can provide a detailed record of fine-scale basin evolution by revealing the temporal and spatial variability of detrital zircon ages within clastic sedimentary successions. This investigation employed detailed sampling of two sedimentary successions in the Methow/Methow-Tyaughton basin of the southern Canadian Cordillera to characterize the heterogeneity of detrital zircon signatures within single lithofacies and assess the applicability of detrital zircon analysis in distinguishing fine-scale provenance changes not apparent in lithologic analysis of the strata. The Methow/ Methow-Tyaughton basin contains two distinct stratigraphic sequences of middle Albian to Santonian clastic sedimentary rocks: submarine-fan deposits of the Harts Pass Formation/Jackass Mountain Group and fluvial deposits of the Winthrop Formation. Although both stratigraphic sequences displayed consistent ranges in detrital zircon ages on a broad scale, detailed sampling within each succession revealed heterogeneity in the detrital zircon age distributions that was systematic and predictable in the turbidite succession but unpredictable in the fluvial succession. These results suggest that a high-density sampling approach permits interpretation of finescale changes within a lithologically uniform turbiditic sedimentary succession, but

\footnotetext{
†E-mail: ksurpless@stanford.edu.
}

heterogeneity within fluvial systems may be too large and unpredictable to permit accurate fine-scale characterization of the evolution of source regions. The robust composite detrital zircon age signature developed for these two successions permits comparison of the Methow/MethowTyaughton basin age signature with known plutonic source-rock ages from major plutonic belts throughout the Cretaceous North American margin. The Methow/ Methow-Tyaughton basin detrital zircon age signature matches best with source regions in the southern Canadian Cordillera, requiring that the basin developed in close proximity to the southern Canadian Cordillera and providing evidence against large-scale dextral translation of the Methow terrane.

Keywords: provenance, zircon, Methow Basin, Canadian Cordillera, Baja BC hypothesis, Kolmogorov-Smirnov test.

\section{INTRODUCTION}

Detrital zircon age distributions from clastic sedimentary strata provide critical constraints on basin evolution, tectonic history, and paleogeography (e.g., Ross and Bowring, 1990; Gehrels and Dickinson, 1995; Mahoney et al., 1999; Gehrels, 2000, and references therein; DeGraaff-Surpless et al., 2002). By identifying a spectrum of grain ages that approximates the age distribution of geologic units within a source region, detrital zircon analysis can define sedimentary provenance and may help characterize spatial and temporal variations in sediment supply to a depocenter. Critical to accurate provenance analysis is the establishment of a detrital zircon age signature that accounts for the influence of sedimentologic and depositional processes on the lateral and vertical distribution of the detrital zircons within sedimentary successions. Within a single sedimentary succession, high-frequency sampling should provide a detailed record of basin evolution, but the reliability of this record depends on adequate characterization of the heterogeneity of the detrital zircon signature.

This investigation utilized a detailed and systematic sampling strategy to examine the temporal and spatial variability of the detrital zircon signature from two sedimentary successions deposited in the same depocenter but under very different depositional conditions. The composite Methow/Methow-Tyaughton basin of the southern Canadian Cordillera contains thick successions of clastic strata deposited in marine and terrestrial environments. The Harts Pass Formation/Jackass Mountain Group succession was deposited in a submarine-fan system in a forearc setting adjacent to a dissected volcanic arc during Albian time, and the overlying Albian-Cenomanian Winthrop Formation was deposited within a braided fluvial system also derived from a dissected volcanic arc. Each succession is dominated by thick deposits of similar and apparently homogeneous feldspathic litharenite, and the depositional setting of each unit is well defined by detailed lithofacies analysis (Coates, 1974; Barksdale, 1975; Kleinspehn, 1985; Haugerud et al., 1996; Kiessling, 1998). We used vari-

GSA Bulletin; August 2003; v. 115; no. 8; p. 899-915; 10 figures; 1 table; Data Repository item 2003104. 
able vertical and horizontal sampling densities in each succession to (1) evaluate the relationship between lithofacies and detrital zircon signatures by characterizing the heterogeneity of detrital zircon signatures within each succession, (2) assess the applicability of detrital zircon analysis in characterizing fine-scale provenance changes not apparent in lithologic analysis of the strata, and (3) develop a composite detrital zircon age signature for both successions that can then be compared to ages in potential source regions to test tectonic models of terrane translation.

The results of this fine-scale detrital zircon analysis demonstrate that the degree of homogenization of detrital zircon age distributions is directly related to the depositional environment. On a broad scale, both the Harts Pass Formation/Jackass Mountain Group and the Winthrop Formation had consistent ranges in detrital zircon ages. However, on a finer scale, both successions displayed significant heterogeneity in the detrital zircon age distributions; greater heterogeneity was present in the fluvial Winthrop Formation than in the turbiditic Harts Pass Formation/Jackass Mountain Group. Furthermore, variability within the turbidite succession was systematic and predictable; heterogeneity in the fluvial succession was unpredictable and therefore difficult to interpret. These results suggest that a highresolution sampling approach permits interpretation of systematic temporal changes within a turbiditic sedimentary succession, such as the Harts Pass Formation, but heterogeneity within fluvial systems, such as the Winthrop Formation, is too large and unpredictable to permit accurate fine-scale characterization of the evolution of source regions, even with a large number of samples. These results also highlight the need for detailed lithofacies analysis prior to development of a sampling strategy designed to elucidate basin evolution.

The robust composite detrital zircon age signature developed for these two successions provides critical constraints on the ages of potential source regions for the Cretaceous strata of the Methow terrane, an allochthonous faultbounded sequence with a controversial tectonic translation history. The Methow/MethowTyaughton basin detrital zircon age signature indicates that the basin most likely developed in close proximity to the southern Canadian Cordillera, providing evidence against largescale translation of the Methow terrane from a southern source region.

\section{SEDIMENTARY SYSTEMS AND SAMPLING STRATEGY}

The scale of the basinal succession is an important consideration in provenance analysis. The degree of sediment homogenization, and therefore homogenization of detrital zircon age distributions, is a direct function of the scale of the system under consideration and the transport mechanisms operative within that system. Ingersoll et al. (1993) demonstrated the effects of variable sampling scale on sand composition in petrofacies analysis, and the same concepts are useful for the establishment of an efficient sampling protocol for detrital zircon analysis. The following basin hierarchy is modified from Ingersoll (1990; Ingersoll et al., 1993):

1. First-order sediment systems are associated with local drainages that sample individual lithologic units or groups of units. Sediment in these systems tends to be immature, and the detrital zircon signature directly reflects the heterogeneity of the source area (Dickinson and Gehrels, 2000). Abrupt lateral and vertical variations in detrital zircon composition may record tectonic events in the source region. These systems tend to be areally restricted and rapidly commingle with adjacent first-order systems.

2. Second-order sediment systems are continental and marginal-marine basins associated with large, coalescing river systems and associated submarine-fan systems that effectively sample at the scale of mountain ranges, including magmatic arcs and fold-and-thrust belts (Ingersoll et al., 1993). Sediment tends to be submature and has undergone substantial modification as a result of weathering and transport. The detrital zircon signature reflects the gradual homogenization of detrital grains, but may be subject to rapid spatial and temporal fluctuations as a function of lithologic heterogeneity and episodic tectonism in the source region.

3. Third-order sediment systems are those associated with large rivers draining significant parts of a continent and include deltaic and shallow-marine sediments along passive continental margins (Ingersoll et al., 1993). Considerable homogenization and compositional stabilization occurs in third-order systems, owing to prolonged chemical and physical disintegration of the principal detrital components and concentration of resistant heavy minerals such as zircon. This homogenization suggests that these systems should be characterized by laterally consistent detrital zircon signatures that vary on the scale of hundreds of kilometers (e.g., Gehrels et al.,
1995). Large river systems and associated deltas built along active margins are also considered third order, but admixtures from less mature systems commonly complicate their detrital signature. Examples include the eastern North American continental shelf and the Amazon deltaic system.

Any individual basin may contain more than one order of sedimentary system; for example, the modern Gulf of Mexico contains first-, second-, and third-order sediment systems, depending on the part of the depocenter studied (Galloway and Williams, 1991).

\section{GEOLOGIC SETTING}

The Methow and Methow-Tyaughton basins of the southern Canadian Cordillera contain Jurassic and Cretaceous strata that overlie allochthonous Triassic oceanic crust of the Methow terrane (Figs. 1 and 2). The Cretaceous parts of the basin contain more than 6 $\mathrm{km}$ of middle Albian to Santonian sedimentary and volcanic rocks that constitute an overall shallowing-upward succession subdivided into two stratigraphic sequences. The lower succession, deposited in the Methow Basin, contains Albian rocks of the Harts Pass Formation and the Jackita Ridge and Little Jack units in Washington State and the upper Jackass Mountain Group in southern British Columbia (Fig. 3; Coates, 1974; Barksdale, 1975). The upper succession, deposited in the Methow-Tyaughton basin, consists of lower Cenomanian to Santonian strata of the Pasayten Group (Fig. 3; Barksdale, 1975; Garver, 1992; Kiessling and Mahoney, 1997). The contact between the Pasayten Group and underlying middle Albian strata of the lower succession is primarily an angular unconformity, although feldspathic sandstone of the Pasayten Group gradationally overlies compositionally similar rocks of the upper Jackass Mountain Group along the preserved eastern margin of the basin. This investigation focuses on middle to Upper Cretaceous fill of the combined Methow/Methow-Tyaughton system; the overall Jurassic to Cretaceous evolution of the basin is complex and beyond the scope of this study.

\section{Structural Setting}

Cretaceous strata overlying the Methow terrane are exposed in an elongate structural block bound on the east by the Pasayten fault system and on the west by the Ross Lake and Fraser-Straight Creek fault systems (Fig. 1). The Methow terrane was imbricated structurally with the Bridge River and Cadwallader 


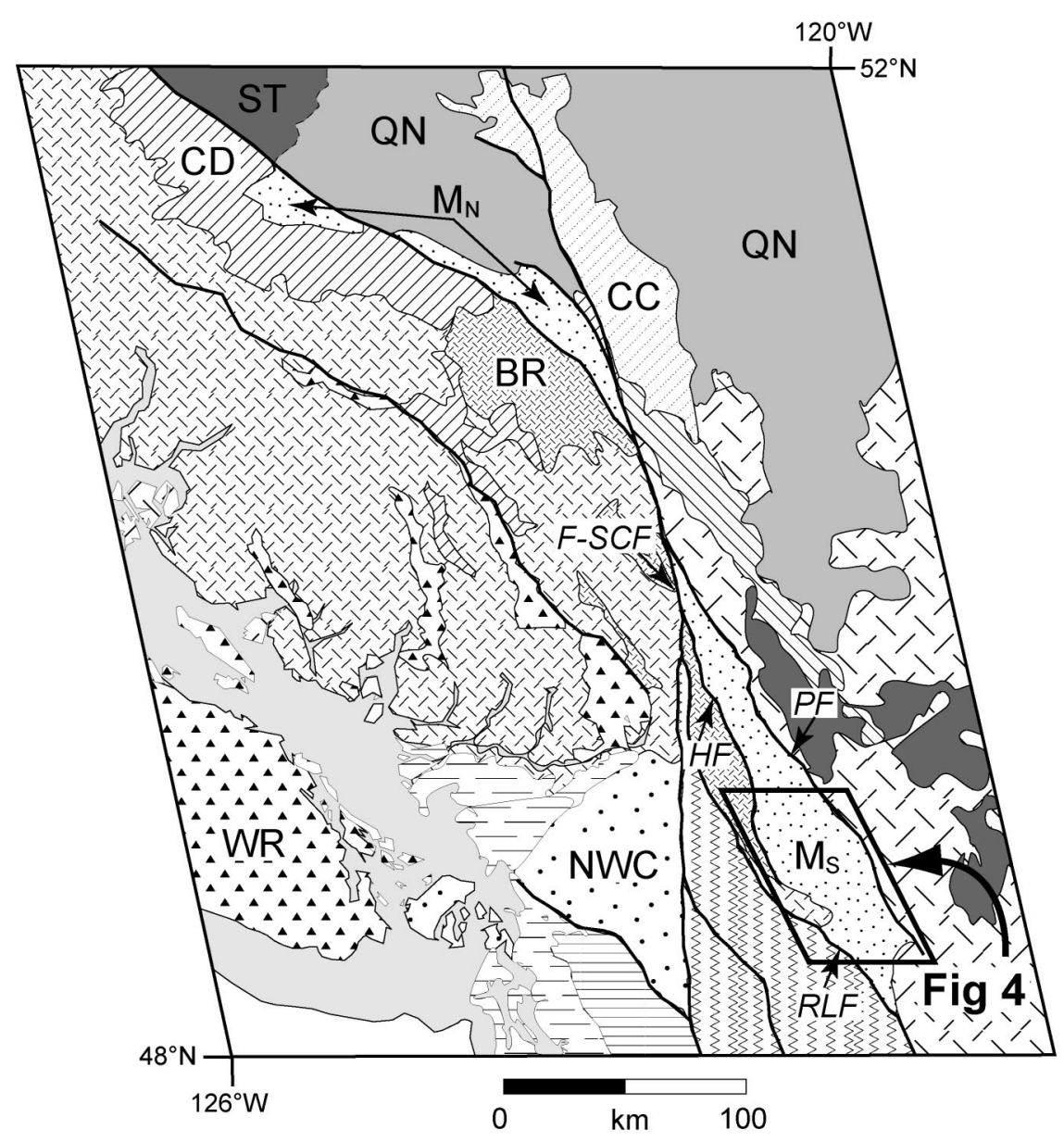

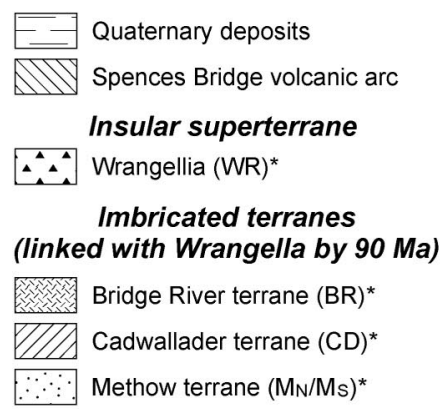

*includes overlying Jurassic-Cretaceous clastic successions

Intermontane superterrane
$\square \quad$ Quesnellia (QN)
$\square$ Stikinia (ST)
$\square$ Cache Creek (CC)

Terranes of uncertain affinity

$\therefore$ Northwest Cascades System (NWC)

Western and Eastern Melange Belts

\section{Crystalline Rocks}

这多多 Cascade Metamorphic Core

S: Coast Plutonic Complex

J-K plutonic rocks

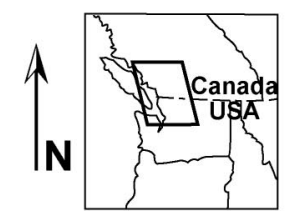

Figure 1. Regional geologic map of the southern Canadian Cordillera, showing distribution of terranes and major structural features (HF-Hozameen fault; RLF—Ross Lake fault; PF_-Pasayten fault; F-SCF_Fraser-Straight Creek fault system). The box labeled Figure 4 shows the location of this study.

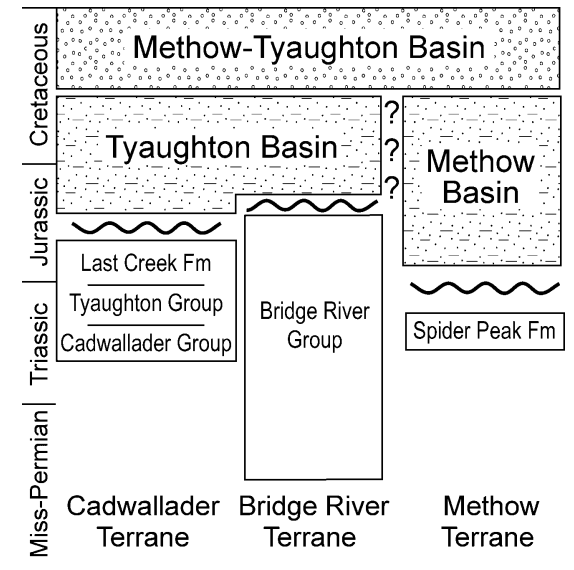

Figure 2. Tectonostratigraphic nomenclature within the southern Canadian Cordillera. Queries indicate timing of proposed stratigraphic linkages (Umhoefer, 1988; Garver, 1992; Mahoney and Journeay, 1993; Mahoney, 1994; Schiarizza and Payie, 1997).

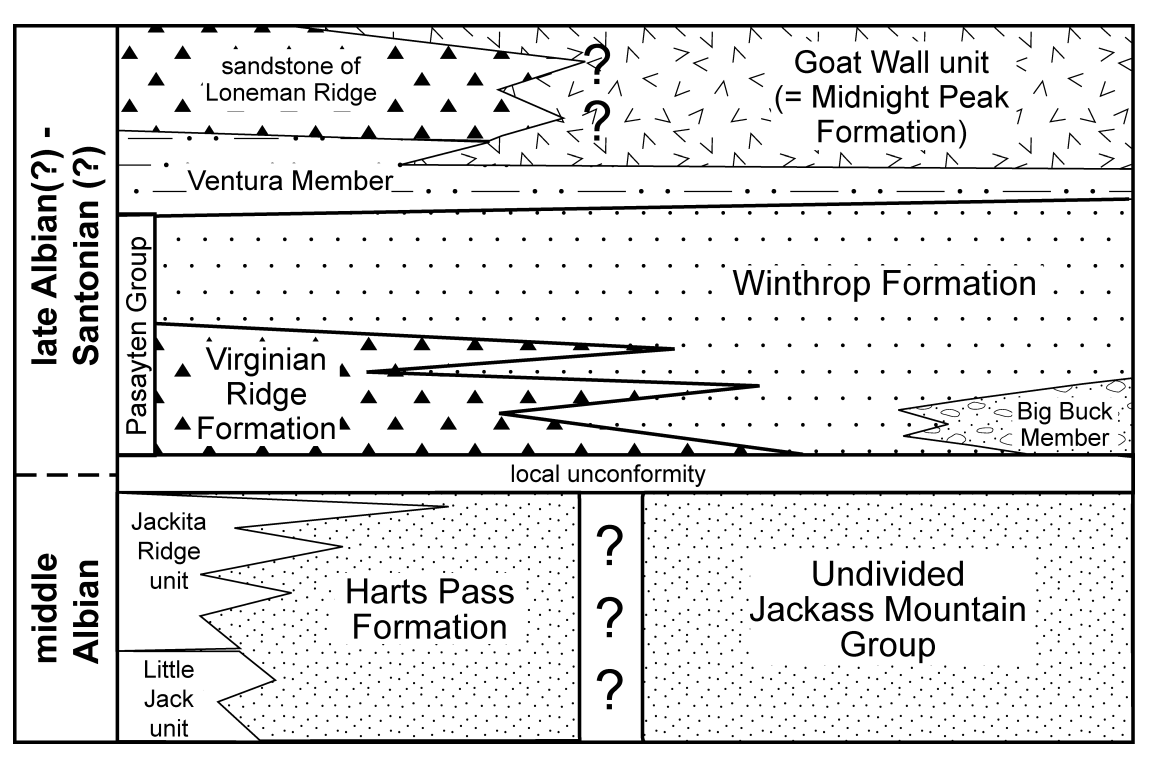

Figure 3. Generalized stratigraphy of the Pasayten Group and underlying strata. Adapted from Coates (1974), Haugerud et al. (1996), and Kiessling (1998). 


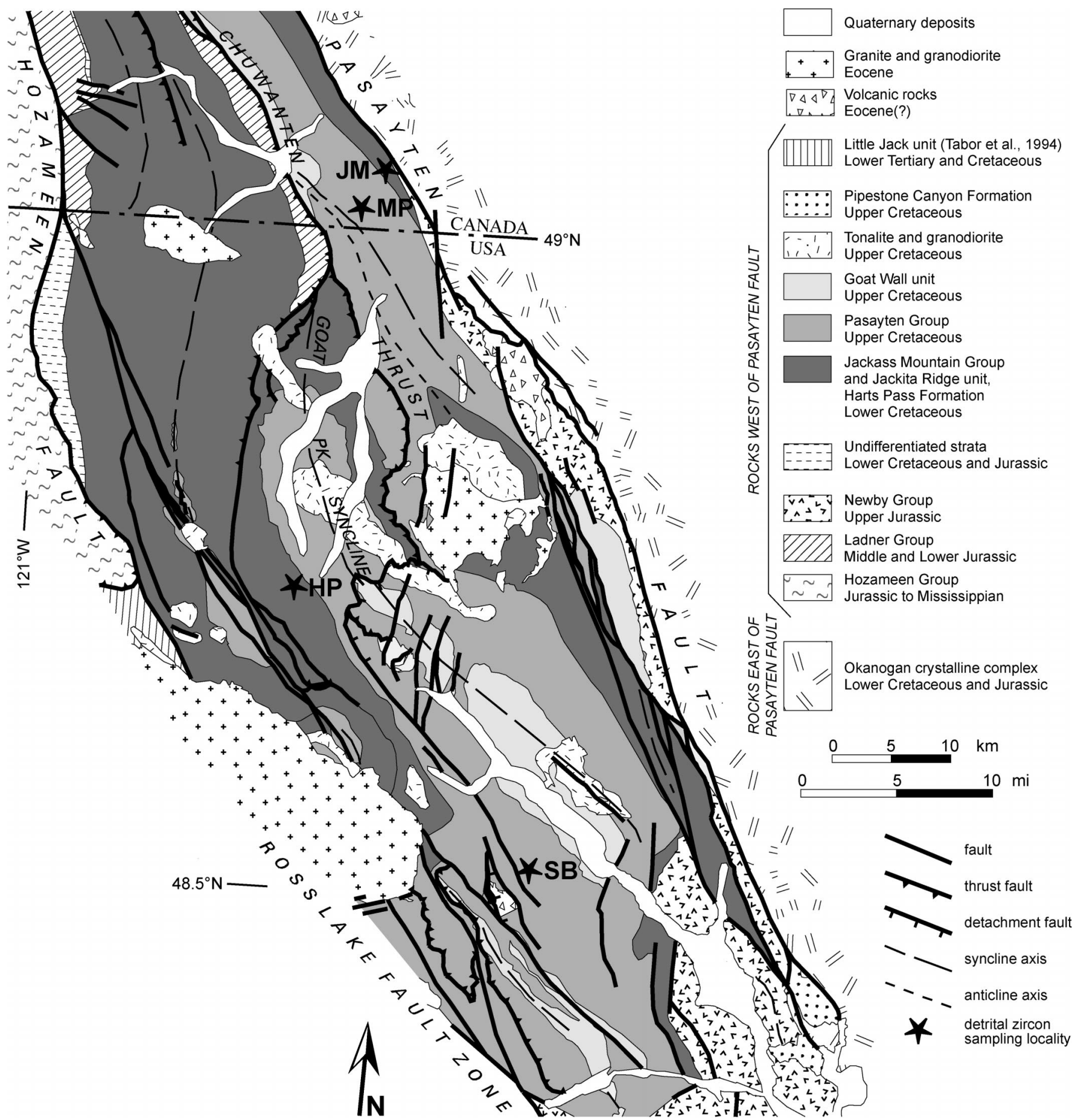

Figure 4. Geologic map of the southern Methow block, showing major structures and rock units discussed in text. Stars indicate the locations of the stratigraphic sections sampled during this study (JM-Jackass Mountain Group, MP-Manning Park, Winthrop Formation, HP-Harts Pass Formation, SB—Sandy Butte, Winthrop Formation). Map compiled from Coates (1974), Bunning (1990), Tabor et al. (1994), Dragovich and Norman (1995), and Haugerud (1999, personal commun.).

terranes along its western margin during Cenomanian time (Figs. 1 and 4; Journeay and Friedman, 1993). Along the eastern margin of the Methow terrane, the Pasayten fault has a multistage deformational history that includes
Late Cretaceous sinistral displacement, Late Cretaceous to Tertiary west-vergent contractional motion, and Tertiary extension (Hurlow, 1993). Seismic reflection data indicate that the Pasayten fault dips eastward, juxtaposing Cre- taceous volcano-plutonic rocks of Quesnellia over sedimentary successions of the Methow/ Methow-Tyaughton basin (Figs. 1, 4; Varsek et al., 1993).

Paleomagnetic data from the Intermontane 
and Insular superterranes have been interpreted to suggest that the modern Pasayten fault is coincident with the principal locus of (1) as much as $3000 \mathrm{~km}$ of dextral translation that occurred between 85 and 50 Ma (e.g., Wynne et al., 1995; Irving et al., 1996), or (2) less than $1500 \mathrm{~km}$ of translation (e.g., Butler et al., 1989; Kodama and Ward, 2001). Therefore, rocks on opposite sides of the modern Pasayten fault may or may not have been in geographic proximity in the Late Cretaceous, and strata of the Methow/Methow-Tyaughton basin may be cut off from their eastern source.

\section{Sedimentary Successions and Basin Order}

The Harts Pass Formation and upper Jackass Mountain Group consist of more than $2.5 \mathrm{~km}$ of medium- to coarse-grained, well-stratified quartzofeldspathic arenite and minor plutonic conglomerate. Underlying Neocomian to lower Albian shallow-marine strata limit the maximum depositional age of the Harts Pass Formation to early to middle Albian. Graded bedding, scours, and loads at the base of beds, parallel and cross-lamination, pelitic rip-up clasts, amalgamated sandstone intervals, laterally continuous beds, and cyclic bedding repetition indicate sub-wave-base turbidite deposition (Coates, 1974; Barksdale, 1975; Tennyson and Cole, 1978; Kleinspehn, 1985; Haugerud et al., 1996). Paleocurrent analysis $(n=122)$ of ripple cross-laminations, groove casts, and other features indicate west-directed transport (mean direction $=296^{\circ}$; Tennyson and Cole, 1978). A westward decrease in bedding thickness, sand/shale ratio, and maximum grain size also supports an eastern source. Tennyson and Cole (1978) interpreted these strata as unchannelized mid-fan deposits of a west-facing middle Albian submarine-fan succession. The apparent lateral and vertical compositional and sedimentologic homogeneity of the succession through more than 2.5 $\mathrm{km}$ of section along more than $60 \mathrm{~km}$ of strike length suggests that the Harts Pass Formation and the upper Jackass Mountain Group represent deposition in a stable second-order sediment system.

The Pasayten Group consists of more than $2.4 \mathrm{~km}$ of medium- to coarse-grained chert lithic to quartzofeldspathic sandstone, polymict conglomerate, and lesser andesitic volcanic flows and associated volcaniclastic strata. Westerly-derived chert lithic detritus of the Virginian Ridge Formation interfingers along the basin axis with easterly-derived quartzofeldspathic arenite of the Winthrop Formation (Fig. 3). These units are gradationally to unconformably overlain by volcanic and volcan- iclastic rocks of the Ventura Member of the Goat Wall unit (Fig. 3; Barksdale, 1975; Tennyson and Cole, 1978; Kiessling and Mahoney, 1997; Kiessling, 1998). This investigation concentrates on the Winthrop Formation of the Pasayten Group, which is early Cenomanian to Coniacian (98-87 Ma) in age, on the basis of detrital zircons, crosscutting dikes, and the age of the overlying Goat Wall unit (Haugerud et al., 1996).

High-angle cross-stratification, lenticular conglomerate, in situ tree stumps, abundant plant debris, subaerial lava flows and breccias, and rare marine bivalves indicate that the $\mathrm{Pa}$ sayten Group was deposited by braided to meandering streams that locally prograded into a marginal-marine environment (Coates, 1974; Barksdale, 1975; Kiessling, 1998). Facies variations, subsidence rates, and the intimate association between sedimentation and contractional deformation suggest that the Pasayten Group accumulated in a complex hybrid forearc/foreland-basin setting resulting from episodic tectonism in an east-vergent fold-andthrust system to the west, coupled with rapid uplift and erosion of a partly dissected volcanic arc assemblage to the east (Haugerud et al., 1996; Kiessling, 1998). The complex stratigraphy and paleocurrent pattern, rapid lateral and vertical compositional changes, and sedimentologic heterogeneity indicate that the Pasayten Group formed in a first- to secondorder sediment system (Kiessling and Mahoney, 1997; Kiessling, 1998).

\section{METHODOLOGY}

\section{Sampling Strategy}

Determination of a detrital zircon age signature that fully characterizes both stratigraphic sequences of the Methow/Methow-Tyaughton basin requires a sampling density sufficiently detailed to permit recognition of temporal and spatial variations in detrital zircon age distributions within continuous and lithologically homogeneous stratigraphic sections.

Coeval stratigraphic sections of the Winthrop Formation were sampled at Sandy Butte in the southern part of the basin and $\sim 75 \mathrm{~km}$ to the north in Manning Park in the northern part of the basin (Fig. 4). Through a detailed analysis of the stratigraphy and sedimentary petrology of the Pasayten Group, Kiessling (1998) demonstrated that the Winthrop Formation was a strikingly homogeneous micaceous feldspathic arenite deposited in a braided fluvial system draining a dissected volcanic arc assemblage. Following the Sandy Butte stratigraphy detailed by Kiessling (1998), we sampled from the base, middle, and upper parts of a 1.5-km-thick section, separating the samples by $\sim 600 \mathrm{~m}$ of true section thickness. To assess the heterogeneity of the detrital zircon signature, we collected samples spaced 10 $\mathrm{m}$ above and $10 \mathrm{~m}$ below the uppermost Winthrop sample. In the northern part of the basin, we followed the same protocol, collecting four samples from the Winthrop Formation in Manning Park, including one sample from the lower part of the formation and three samples from the middle of the formation spaced $\sim 15$ vertical meters apart.

We used a similar procedure to sample the Harts Pass Formation in the southern part of the basin (Fig. 4), sampling from the base, middle, and upper levels of the stratigraphic section with $\sim 1000 \mathrm{~m}$ of section between samples. Three samples spaced $15 \mathrm{~m}$ apart were collected from the uppermost Harts Pass Formation to assess rapid variations in detrital zircon signature. Sampling of the coeval Jackass Mountain Group in the northern part of the basin was hampered by a lack of biostratigraphic control. Our collections were limited to two samples, spaced $\sim 500 \mathrm{~m}$ apart, from the upper part of the Jackass Mountain Group as defined by Coates (1974).

\section{Analytical Methods}

Samples consisted of 2-6 kg of mediumgrained lithic feldspathic to feldspathic arenite. Zircon was isolated following standard density and magnetic separation techniques (see Appendix). To eliminate bias introduced during handpicking, no visual morphologic or color differentiation was made. The total zircon grain population was subdivided en masse to provide a random subset of the entire population. Grains were mounted in epoxy, polished to half of mean grain thickness, and imaged with transmitted and reflected light and cathodoluminescence to illuminate internal structures. No distinct inherited cores were visible in cathodoluminescence, and many grains showed well-developed oscillatory zoning.

The statistical adequacy assessment of Dodson et al. (1988) states that 59 grains must be analyzed to achieve $95 \%$ confidence of finding every population that exists at the $5 \%$ level in a given sample, according to the equation $P$ $=(1-f)^{n}$, where $P$ is the probability of missing a provenance component, $f$ is the proportion of that component in the total population, and $n$ is the number of grains analyzed. All of the samples presented here consist of 60 individual analyses.

$\mathrm{Pb} / \mathrm{U}$ ratios were calibrated with reference 

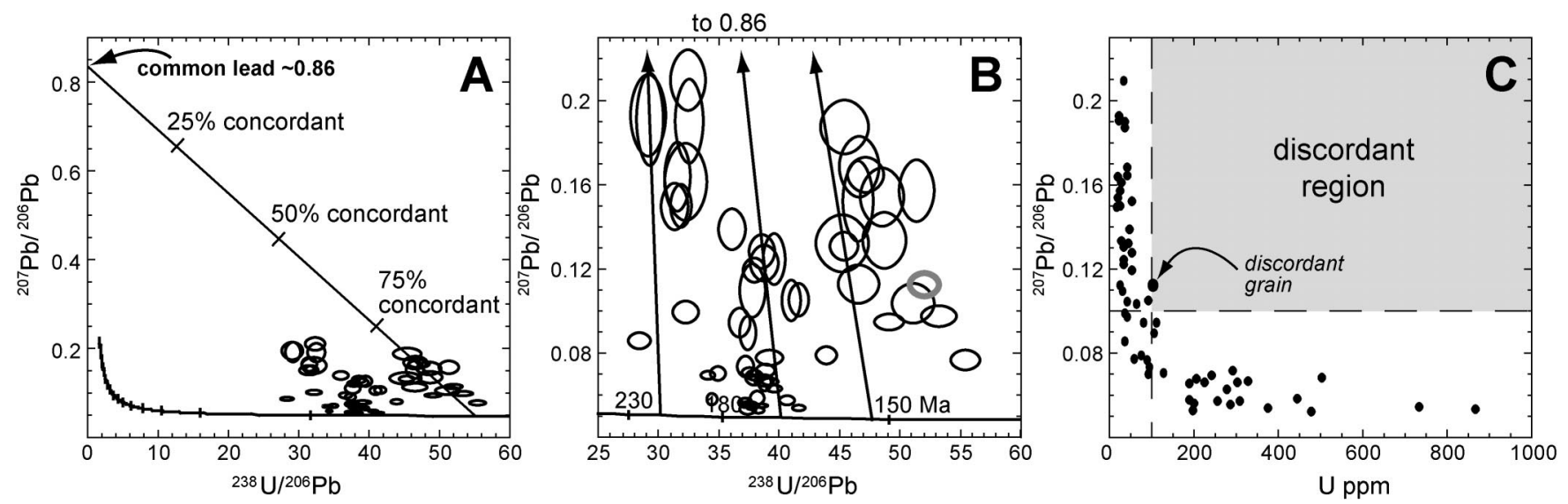

Figure 5. Discordance of young zircon is estimated with Tera-Wasserburg concordia diagrams. (A) Uncorrected data for sample KD3 (lower Harts Pass Formation) are plotted on a Tera-Wasserburg concordia, and discordance is estimated by using a mixing line between a common-Pb ratio and concordia. KD3 data fall within $20 \%$ of concordia. (B) A closer look at KD3 data reveals a strong tendency off concordia toward the common-Pb ratio. (C) A plot of $\mathrm{U}$ concentration against ${ }^{207} \mathrm{~Pb} /{ }^{206} \mathrm{~Pb}$ ratios (a reasonable proxy for discordance where ages are young enough to plot on the near-horizontal part of the Tera-Wasserburg concordia) shows that the grains with low $U$ concentrations are the most discordant.

to standard zircon AS57 (standard age $=1099$ Ma; Paces and Miller, 1993), which was analyzed after every fourth or fifth analysis of an unknown zircon (see Appendix). U and Th concentrations were calibrated to standard SL13 (Williams, 1998). All ages reported are based on the measured ${ }^{206} \mathrm{~Pb} /{ }^{238} \mathrm{U}$ ratio calibrated to the ${ }^{206} \mathrm{~Pb} / 238 \mathrm{U}$ ratio in the AS57 standard and corrected for common $\mathrm{Pb}$ by assuming concordance and using the model of Cumming and Richards (1975). ${ }^{1}$

\section{Assessing and Interpreting Discordance}

Because of the small amount of radiogenic $\mathrm{Pb}$ in Mesozoic zircon, ${ }^{207} \mathrm{~Pb} / 206 \mathrm{~Pb}$ and ${ }^{207} \mathrm{~Pb} /$ ${ }^{235} \mathrm{U}$ ages determined by the ion microprobe have high uncertainties and cannot be used to evaluate discordance. However, if we assume that common $\mathrm{Pb}$ is the most significant factor in producing discordance toward a common$\mathrm{Pb}{ }^{207} \mathrm{~Pb} /{ }^{206} \mathrm{~Pb}$ ratio $(0.86 \pm 0.06$; Cumming and Richards, 1975), then a common- $\mathrm{Pb}$ correction provides acceptable estimates of true ages. This is a reasonable assumption for the Mesozoic zircon grains in the Methow/MethowTyaughton basin for several reasons: (1) grains show well-developed oscillatory zoning and no visible evidence for inherited cores, suggesting that they are first-cycle magmatic grains (Hanchar and Miller, 1993); (2) the grains plot in clusters on a Tera-Wasserburg

${ }^{1}$ GSA Data Repository item 2003104, Age data for Methow/Methow-Tyaughton basin samples, is available on the Web at http://www.geosociety.org/ pubs/ft2003.htm. Requests may also be sent to editing@geosociety.org. diagram, lending significance to the ages because the probability of grains with complex discordance histories falling into clusters is slight (Fig. 5; Gehrels, 2000); (3) data that plot above concordia fit a mixing line toward a ${ }^{207} \mathrm{~Pb} /{ }^{206} \mathrm{~Pb}$ ratio for common $\mathrm{Pb}(0.86)$ and do not fit a mixing line toward older ages (Figs. 5A and 5B); and (4) the most discordant data generally have the lowest concentration of U (less than $100 \mathrm{ppm}$ ). Low U concentration means little radiogenic $\mathrm{Pb}$ in the zircon (Fig. 5C), so a tiny amount of common $\mathrm{Pb}$ in the sample has a much greater influence on measured $\mathrm{Pb}$ ratios.

The Tera-Wasserburg concordia diagram provides a graphical estimate of discordance in young zircon grains by showing uncorrected ${ }^{207} \mathrm{~Pb} /{ }^{206} \mathrm{~Pb}$ ratios plotted against uncorrected ${ }^{238} \mathrm{U} / 206 \mathrm{~Pb}$ ratios (Fig. 5). Discordance of Mesozoic grains was estimated by determining where data fall on a mixing line from the common- $\mathrm{Pb}$ value $\left({ }^{207} \mathrm{~Pb} /{ }^{206} \mathrm{~Pb}\right.$ ratio of 0.86$)$ through the data to concordia. Data presented herein include grains within $5 \%$ of concordance as well as more discordant grains with very low U concentrations. Data more than $5 \%$ discordant $\left({ }^{207} \mathrm{~Pb} / 206 \mathrm{~Pb}>0.1\right)$ and with $\mathrm{U}$ concentrations greater than $100 \mathrm{ppm}$ have been removed from further consideration. Out of 960 grains analyzed during this study, 31 $(3.2 \%)$ were deemed unsuitable for consideration.

\section{Statistical Methods}

Detrital zircon age data are plotted as histograms with superimposed probability den- sity distributions in order to represent both the age measurement and the associated uncertainty (Figs. 6A-9A). To assess the heterogeneity of the age distributions within each of the four stratigraphic sections, we compared each sample age distribution within a stratigraphic section with every other sample age distribution within the same stratigraphic section by using cumulative probability plots and the Kolmogorov-Smirnov (K-S) two-sample test (Figs. 6B-9B and Table 1; Berry et al., 2001). The K-S test is a nonparametric statistical method (it is independent of any assumptions about the probability distribution of a sample and allows comparison of both age values [peak locations] and distributions [peak shapes]) that returns the probability $(P)$ that two samples were drawn from the same population (e.g., Press et al., 1986; Berry et al., 2001). The higher the $P$ value, the more likely it is that the two age distributions were drawn from the same population. To be $95 \%$ confident that two populations are not statistically different, the $P$ value must exceed 0.05 . The cumulative probability curves, combined with the $P$ values, provide a useful means of assessing heterogeneity within each stratigraphic succession, comparing the level of heterogeneity between different sections, and observing trends within each section.

\section{RESULTS}

\section{Harts Pass Formation and Jackass Mountain Group}

The detrital zircon age distributions of the Harts Pass Formation are characterized by a 
Harts Pass Formation
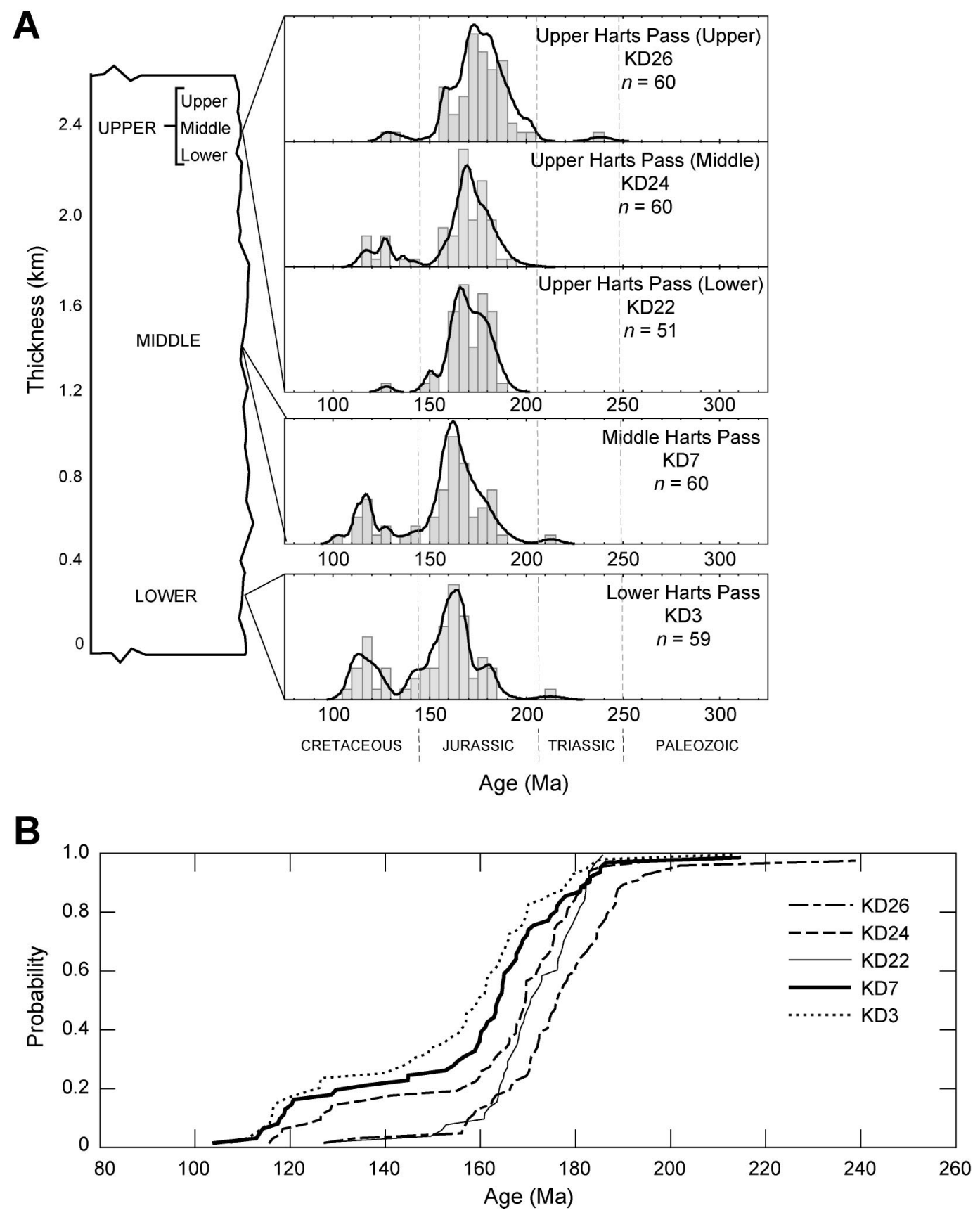

Figure 6. (A) Age histograms and probability density distributions for the Harts Pass Formation. Detrital zircon age distributions are keyed to a cartoon stratigraphic section to illustrate sample spacing. (B) Cumulative probability plots for all samples in the stratigraphic section.

large Middle Jurassic peak and smaller Early Jurassic and Cretaceous peaks throughout the stratigraphic section (Fig. 6A). Samples from the lower and middle parts of the section, separated by $\sim 1000 \mathrm{~m}$, are strikingly similar $(P$ $=0.398$; Table 1$)$ and are characterized by a prominent bimodal Jurassic age distribution (ca. 185-180 Ma and 165-160 Ma), a smaller
Early Cretaceous peak (ca. 120-115 Ma), and a few Triassic (older than $200 \mathrm{Ma}$ ) ages. Three closely spaced samples $(\sim 15 \mathrm{~m}$ between samples) from the upper part of the section have $P$ values ranging from 0.002 to 0.254 (Table 1), indicating significant similarities. Both the reduction in the Early Cretaceous peak in the uppermost samples and the increasing age of the Jurassic peak up-section indicate a trend toward older detrital zircon grains higher in the section.

Statistical analysis suggests that the Harts Pass Formation is heterogeneous (only 2 out of 10 comparisons with $P>0.05$; Table 1 ). However, the consistency in the overall distribution of the Harts Pass Formation age peaks 

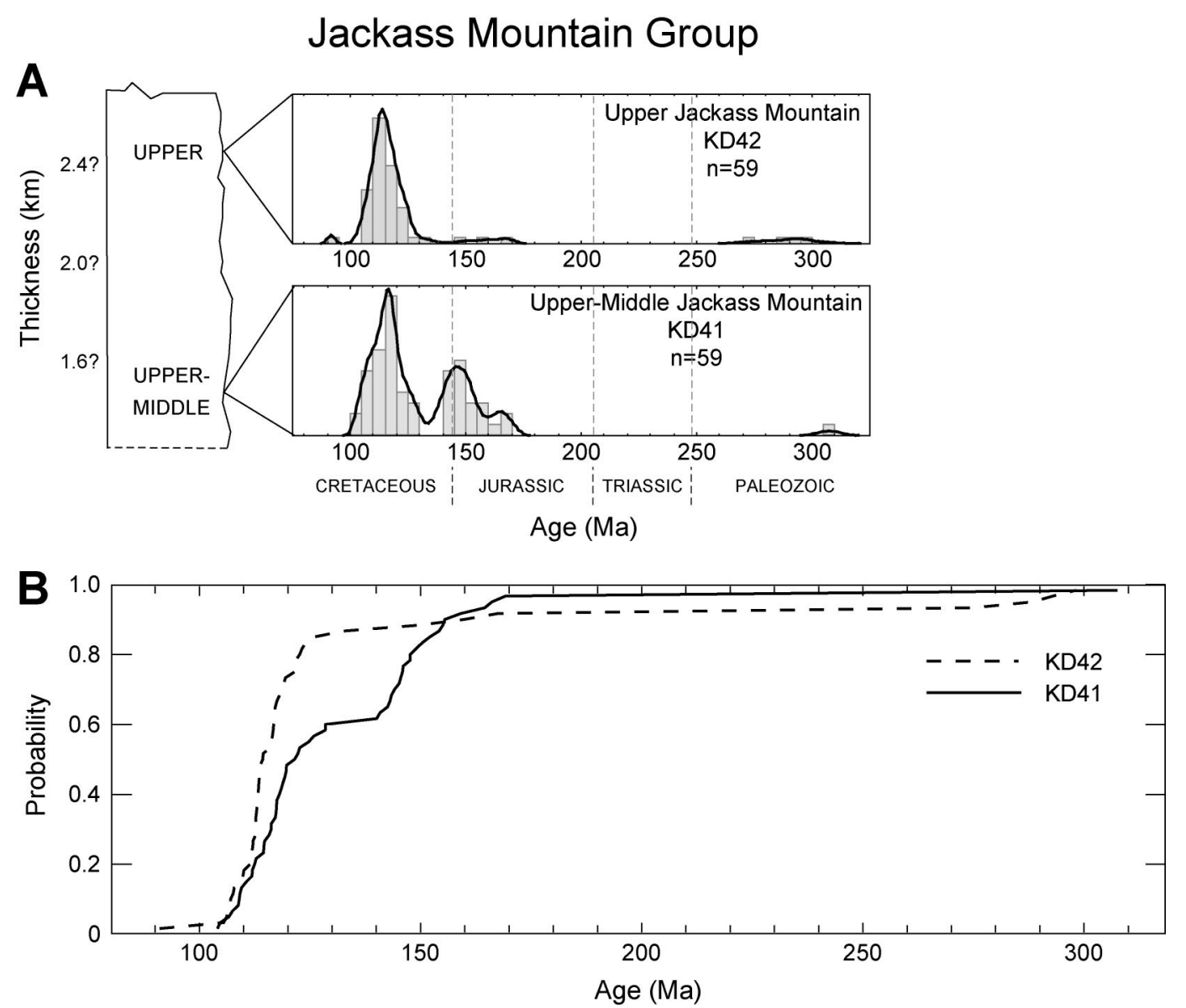

Figure 7. (A) Age histograms and probability density distributions for the Jackass Mountain Group. Detrital zircon age distributions are keyed to a cartoon stratigraphic section to illustrate sample spacing. (B) Cumulative probability plots for all samples in the stratigraphic section.

is evident in the graphical comparisons presented in Figure 6. The cumulative probability curves throughout the section have a similar shape (Fig. 6B), indicating that the major peak shapes throughout the stratigraphic section are similar; the greatest variation occurs in the younger part of the distributions. In addition, the data show a systematic trend toward older ages up-section (Fig. 6B).

The two Jackass Mountain Group detrital zircon age distributions are dominated by younger ages relative to the Harts Pass Formation age distributions and also contain a small number of Carboniferous to Early Permian ages (Fig. 7A). Both samples display prominent Early Cretaceous peaks (ca. 120$110 \mathrm{Ma}$ ), and the lower sample contains a significant Late Jurassic peak (ca. 150-140 Ma) that is absent in the upper sample. Statistical comparison of the two samples illustrates that the younger part of the age distribution (younger than $120 \mathrm{Ma}$ ) is very similar between samples (Fig. 7B), but significant deviation between samples exists in the older detrital zircon populations as a result of the near absence of Jurassic zircons in the uppermost sample, resulting in a low $P$ value of 0.003 .

Further characterization of the variability of the detrital zircon age signatures within the Jackass Mountain Group and statistical comparison of the Jackass Mountain Group and the Harts Pass Formation is hindered by the lack of precise biostratigraphic control. Examination of the data suggests that both Jackass Mountain Group samples and the lower two Harts Pass Formation samples contain the same major peaks (Early Cretaceous and Jurassic) in reverse proportion, suggesting that the Jackass Mountain Group may be correlative with the lower part of the Harts Pass succession.

\section{Winthrop Formation}

The Winthrop Formation in the southern part of the Methow basin has a lower level of heterogeneity than the Harts Pass Formation (4 out of 10 comparisons with $P>0.05$; Table
1), but the variability in the Winthrop is not as systematic as in the Harts Pass Formation (Fig. 8). The lowest sample, collected near the base of the section at Sandy Butte, displays peaks at ca. $165 \mathrm{Ma}$, ca. $150 \mathrm{Ma}$, and 120$110 \mathrm{Ma}$ and has a minor component of late Paleozoic grains. The lower sample differs significantly from all samples up-section (no comparisons with $P>0.05$; Table 1), and there is a stronger degree of similarity between the middle sample and the three upper samples than between the middle and the lower samples (Table 1). The middle sample at Sandy Butte, collected $\sim 1000 \mathrm{~m}$ above the lowermost sample, is dominated by an Early Jurassic peak (ca. 190-175 Ma) that is absent lower in the section. Conversely, the prominent Early Cretaceous peak (120-110 Ma) evident in the lower sample is strongly diminished in the middle sample. The three samples from the upper part of the section are dominated by bimodal Jurassic peaks (ca. 175-170 and 165-155 Ma) and are quite homogeneous $(P$ values range from 0.08 to 0.75 ; Table 1$)$, 


\section{Winthrop Formation at Sandy Butte}
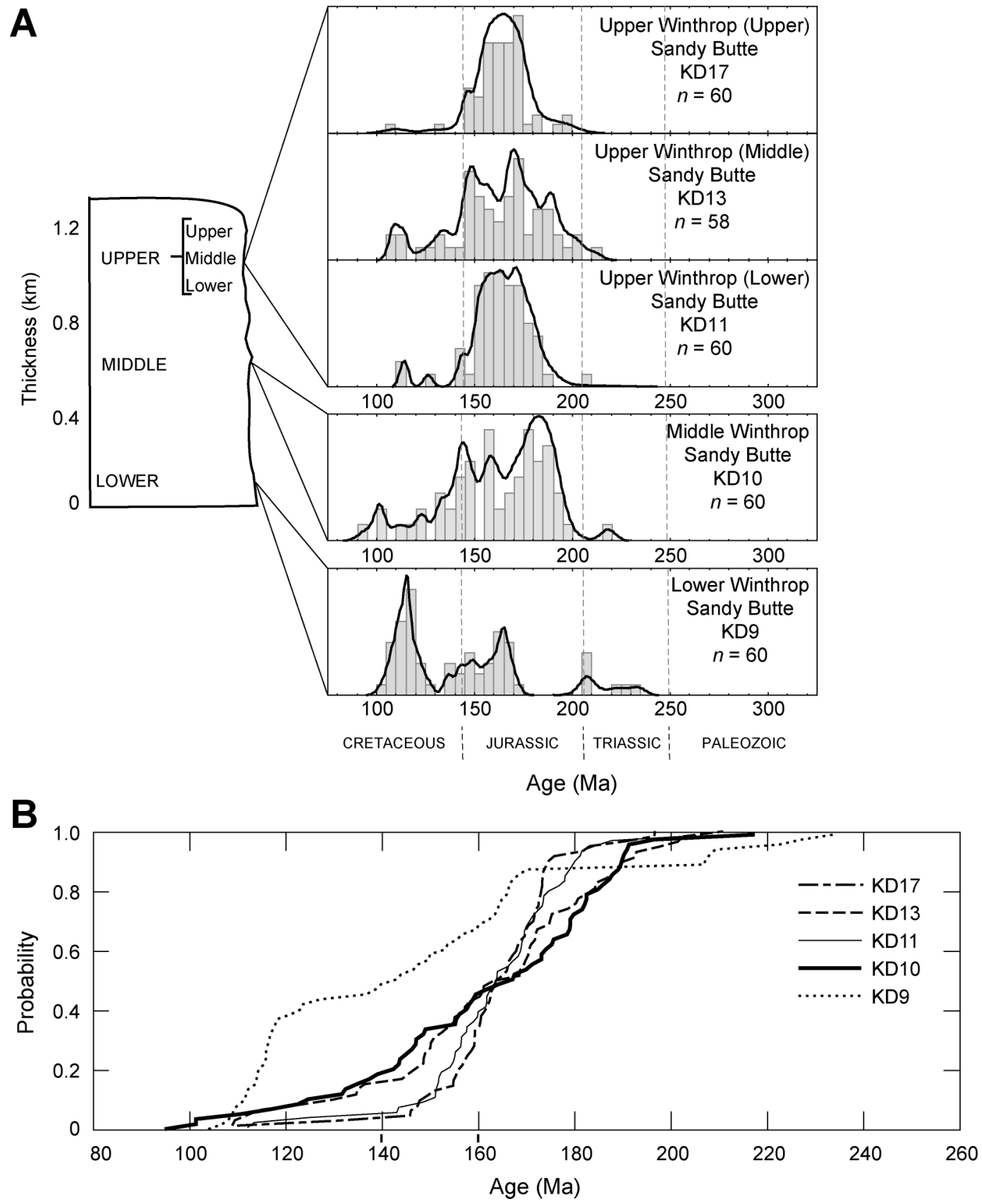

Figure 8. (A) Age histograms and probability density distributions for the Winthrop Formation at Sandy Butte. Detrital zircon age distributions are keyed to a cartoon stratigraphic section to illustrate sample spacing. (B) Cumulative probability plots for all samples in the stratigraphic section.

although the middle of the three samples displays an Early Jurassic peak (ca. $190 \mathrm{Ma}$ ) not evident in the other upper samples.

The sample suite from the northern Winthrop Formation at Manning Park is the most heterogeneous; five comparisons resulted in $P$ $=0$, and only one comparison resulted in $P$ $>0.05$ (Fig. 9 and Table 1). A Late Jurassic peak (ca. $160 \mathrm{Ma}$ ) dominates the lowermost sample and is greatly diminished in two of the three samples higher in the section. The upper three closely spaced samples differ significantly from each other and the lower sample: the lowest of the three samples contains major Late Triassic to Early Jurassic peaks, the middle sample displays a shift to younger ages with peaks at ca. 175-165 Ma and ca. 124$120 \mathrm{Ma}$, and the upper sample contains a range of ages including an Early Cretaceous peak (135-110 Ma), and bimodal Jurassic peaks (ca. 170 and $155 \mathrm{Ma}$ ). The upper two of the closely spaced samples in the middle of the formation are similar $(P=0.179)$, but they differ from both stratigraphically adjacent 


\section{Winthrop Formation at Manning Park}
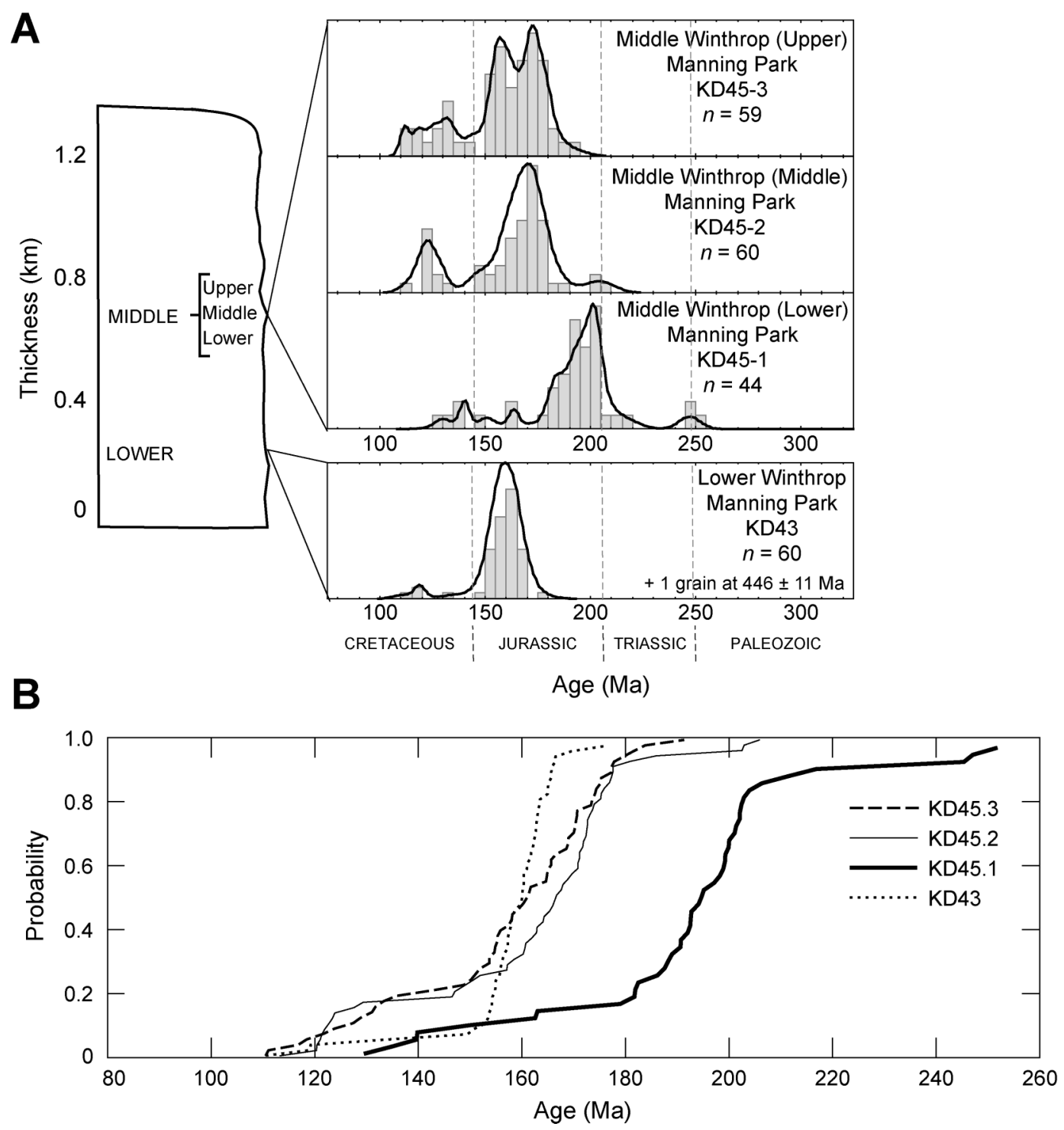

Figure 9. (A) Age histograms and probability density distributions for the Winthrop Formation at Manning Park. Detrital zircon age distributions are keyed to a cartoon stratigraphic section to illustrate sample spacing. (B) Cumulative probability plots for all samples in the stratigraphic section. The outlier age 446 Ma has been removed from the cumulative probability plot.

samples and from the sample near the base of the section $(P=0)$. The variable shapes of the cumulative percentile curves and the low $P$ values suggest that the variability within the formation is nonsystematic (Fig. 9B and Table $1)$.

\section{DISCUSSION}

\section{Sedimentologic Implications}

Our data from Methow/Methow-Tyaughton strata provide general constraints on the provenance of the basin and demonstrate the in- herent heterogeneity of detrital zircon populations within even lithologically uniform stratigraphic successions. The heterogeneity evident in the fluvial Winthrop Formation suggests that detrital zircon analysis, although useful for addressing large-scale provenance questions, may be of limited utility in addressing detailed basin-evolution questions. On a broad scale, both the Harts Pass Formation/ Jackass Mountain Group and the Winthrop Formation display consistent ranges in detrital zircon ages, strongly dominated by Jurassic and Cretaceous ages with a few older ages. Both are lithologically uniform successions of feldspathic litharenite derived from essentially the same dissected volcanic arc, but deposited in different depositional settings.

Because basin order and source heterogeneity are major controls on the extent of compositional homogeneity within a sedimentary succession (Ingersoll, 1990; Ingersoll et al., 1993), sampling strategies utilized in detrital zircon provenance investigations must be guided by variations in sedimentary facies and detrital-mineral assemblages that record broad changes in source-region character and depositional setting (e.g., Ingersoll, 1983). We anticipated that the Harts Pass Formation/Jack- 
TABLE 1. COMPARISON OF DETRITAL ZIRCON AGE SPECTRA USING THE K-S STATISTIC

\begin{tabular}{|c|c|c|c|c|c|}
\hline Stratigraphic unit & Sample & KD26 & KD24 & KD22 & KD7 \\
\hline \multirow[t]{2}{*}{ Harts Pass } & $\begin{array}{l}\text { KD24 } \\
\text { KD22 } \\
\text { KD7 } \\
\text { KD3 }\end{array}$ & $\begin{array}{l}0.002 \\
0.035 \\
0.000 \\
0.000\end{array}$ & $\begin{array}{l}0.254 \\
0.013 \\
0.000\end{array}$ & $\begin{array}{l}0.001 \\
0.000\end{array}$ & 0.398 \\
\hline & Sample & KD42 & & & \\
\hline \multirow[t]{2}{*}{ Jackass Mountain } & KD41 & 0.003 & & & \\
\hline & Sample & KD45.3 & KD45.2 & KD45.1 & \\
\hline \multirow[t]{2}{*}{$\begin{array}{l}\text { Winthrop } \\
\text { (Manning Park) } \\
\end{array}$} & $\begin{array}{c}\text { KD45.2 } \\
\text { KD45.1 } \\
\text { KD43 }\end{array}$ & $\begin{array}{l}0.179 \\
0.000 \\
0.000\end{array}$ & $\begin{array}{l}0.000 \\
0.000\end{array}$ & 0.000 & \\
\hline & Sample & KD17 & KD13 & KD11 & KD10 \\
\hline $\begin{array}{l}\text { Winthrop } \\
\text { (Sandy Butte) }\end{array}$ & $\begin{array}{c}\text { KD13 } \\
\text { KD11 } \\
\text { KD10 } \\
\text { KD9 }\end{array}$ & $\begin{array}{l}0.080 \\
0.750 \\
0.013 \\
0.000\end{array}$ & $\begin{array}{l}0.137 \\
0.849 \\
0.001\end{array}$ & $\begin{array}{l}0.042 \\
0.000\end{array}$ & 0.002 \\
\hline
\end{tabular}

Notes: Numbers refer to the probability $(P)$ that the two samples are derived from the same zircon population. The higher the $P$ value, the more likely it is that the two age distributions were drawn from the same population.

ass Mountain Group succession would display a relatively homogeneous detrital zircon signature reflecting the well-mixed character of a submarine-fan turbidite complex and that the Winthrop Formation would display a more heterogeneous detrital zircon signature characteristic of a fluvial succession fed by a number of individual drainages. In fact, both successions contain significant heterogeneity, but the variability between samples is much more systematic and therefore predictable in the Harts Pass Formation than in the Winthrop Formation. In the Harts Pass Formation, there is a gradual decrease in the prominence of the Early Cretaceous peak and a gradual shift toward slightly older Jurassic peak ages vertically up-section, suggesting a decrease through time in the importance of the Early Cretaceous source relative to older sources, perhaps indicative of an unroofing sequence (Fig. 6). This systematic variation in the Harts Pass Formation strata reveals a fine-scale evolution from younger to older age distributions within the turbiditic succession that is not obvious from lithology alone. Further, the overall uniformity of peak shapes and distribution within the section suggests that a relatively low sampling density may be sufficient to characterize the detrital zircon age distribution in turbidite successions.

The Winthrop Formation displays a more heterogeneous detrital zircon age signature, with significant differences within and between sections. The nonsystematic variations and low $P$ values in the Winthrop detrital zircon age signature, especially at the Manning Park locality, suggest that these strata accumulated in a depositional setting characterized by abrupt changes in detrital input, perhaps resulting from a combination of active tectonism, heterogeneous source region, and limited mixing of sediment derived from different areas within the source region. Streams and rivers transporting detritus to the basin likely were influenced by magmatic and tectonic events in the source region that may have changed local topography and altered drainage patterns from source to basin. Thus, the detrital zircon signature in the Winthrop Formation is less predictable and requires a high sampling density to adequately characterize the provenance of the succession and to begin to interpret fine-scale changes within the succession.

These results suggest that high-resolution detrital zircon analysis does permit fine-scale interpretation within sedimentologically homogeneous successions, such as turbidite sequences within the Harts Pass Formation, but that heterogeneity within fluvial systems like the Winthrop Formation is too unpredictable to permit accurate fine-scale characterization of the evolution of source regions with a reasonable number of samples. Furthermore, the presence of significant heterogeneity in detrital zircon age distributions from a single lithologically uniform sedimentary succession that was derived from one source region suggests that caution should be used when conducting a statistical comparison of detrital zircon distributions from different stratigraphic successions (e.g., Berry et al., 2001). The fact that two stratigraphic successions display statistically different detrital zircon populations (i.e., K-S probability values $<0.05$ ) does not require separate and distinct source regions, but may reflect tectonic and geomorphic evolution of a single source region. Conversely, given the level of heterogeneity observed in samples known to be from the same source area, statistically similar populations (i.e., high K-S probability values) would provide extremely compelling evidence that two distributions were derived from a common source.

\section{Paleogeographic Implications}

The Methow/Methow-Tyaughton basin is a fault-bounded sedimentary basin without definitive linkage to its source region. Controversial paleomagnetic data suggest that the basin (and the associated Insular superterrane) may have undergone large-scale northward latitudinal translation (e.g., Beck et al., 1981; Wynne et al., 1995; Irving et al., 1996; Enkin et al., 2003), potentially originating as far south as central Mexico $\left(\sim 25^{\circ} \mathrm{N}\right)$. Conversely, structural data, basin reconstructions, timing constraints, and alternate interpretations of paleomagnetic data indicate that the basin developed at or near its current latitude and perhaps was trapped east of the Insular superterrane during sinistral (i.e., southward) translation in Cretaceous time (e.g., Butler et al., 1989; Miller et al., 1993; Umhoefer and Miller, 1996; Kodama and Ward, 2001). Analysis of the detrital zircon populations within Methow/Methow-Tyaughton strata may link the basin to its source area, providing constraints on the amount of basin translation since strata deposition.

\section{Establishing a Detrital Zircon Signature}

A combination of several age groups produces a detrital zircon pattern that can be more confidently linked to a specific source region than any single age group (Gehrels, 2000). Accordingly, we combined all grain populations from each sedimentary succession to produce composite detrital zircon signatures that characterize Methow/Methow-Tyaughton basin strata during its deposition between ca. 100 and $87 \mathrm{Ma}$ (Fig. 10). Although both the basin and the source region may contain zircon ages not included in the age ranges defined in the detrital zircon signature, any potential source region for the Methow/ Methow-Tyaughton basin must contain the ages that are represented in the basin's detrital zircon signature. Thus, the detrital zircon signature for the Methow/Methow-Tyaughton basin serves as a guide for comparing detrital zircon ages present in the Methow/MethowTyaughton strata to potential source regions. 


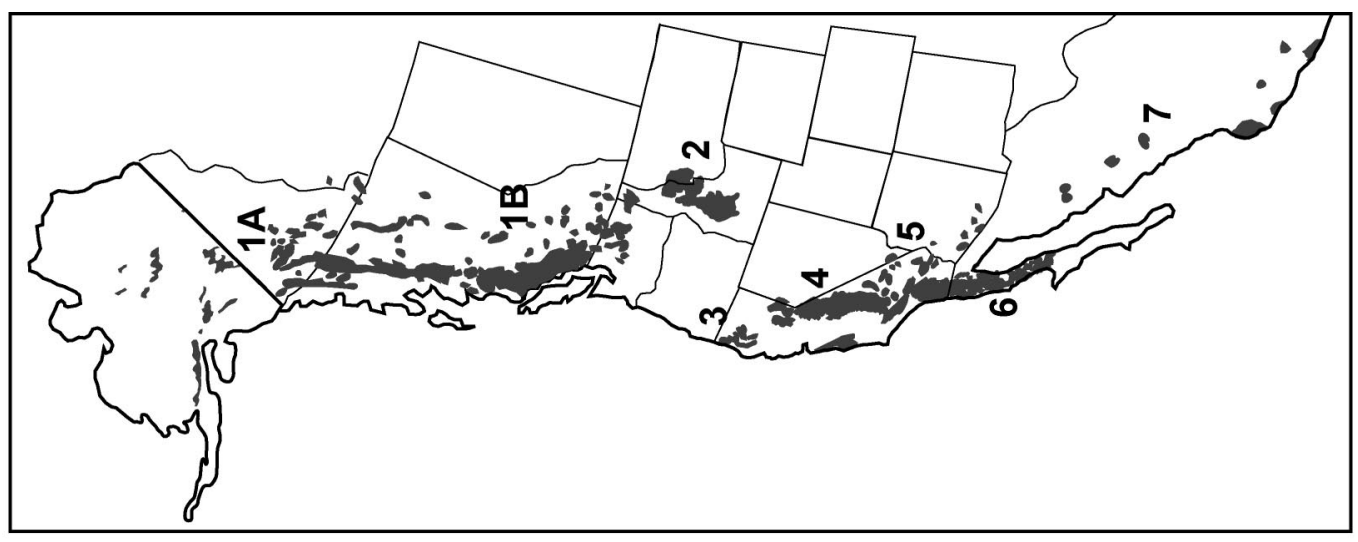

\begin{tabular}{|c|c|c|c|c|c|c|c|c|c|c|c|}
\hline \multirow{9}{*}{ 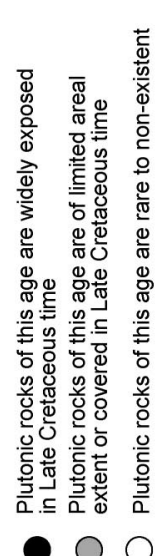 } & $\begin{array}{l}\sum_{0}^{\pi} \\
0 \\
\frac{0}{1} \\
\frac{1}{0}\end{array}$ & 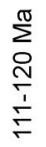 & $\begin{array}{l}\sum_{0}^{\pi} \\
\stackrel{M}{N} \\
\frac{M}{N} \\
\stackrel{N}{N}\end{array}$ & $\begin{array}{l}\frac{\sum^{\pi}}{O} \\
\frac{0}{+} \\
\frac{1}{m}\end{array}$ & $\begin{array}{l}\sum_{0}^{\pi} \\
\frac{0}{0} \\
\frac{1}{\square} \\
\frac{1}{\square}\end{array}$ & $\begin{array}{l}\sum_{0}^{\pi} \\
\frac{0}{0} \\
\frac{1}{1} \\
\frac{1}{n}\end{array}$ & $\begin{array}{l}\sum_{0}^{\pi} \\
0 \\
\frac{0}{1} \\
\frac{1}{0}\end{array}$ & $\begin{array}{l}\frac{\sum^{\infty}}{0} \\
\frac{\infty}{\Gamma} \\
\frac{1}{N}\end{array}$ & \begin{tabular}{l}
$\frac{\sum^{\infty}}{\circ}$ \\
$\frac{0}{\sigma}$ \\
$\frac{1}{\infty}$ \\
\hdashline
\end{tabular} & $\begin{array}{l}\sum^{\pi} \\
\circ \\
\stackrel{D}{N} \\
\stackrel{1}{\sigma} \\
\sigma\end{array}$ & \\
\hline & & O & & O & $\bigcirc$ & $\mathrm{O}$ & & O & O & O & 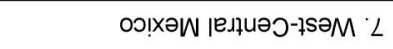 \\
\hline & 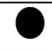 & O & & 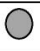 & O & O & O & O & $\mathrm{O}$ & $\mathrm{O}$ & səб̂uey de|nsu!̣əd '9 \\
\hline & O & O & O & $\mathrm{O}$ & O & O & & O & $\mathrm{O}$ & O & елоиоS-әле!oW 'G \\
\hline & O & & & O & O & O & & O & O & 0 & ереләN Euə!s 't \\
\hline & O & O & O & 0 & O & O & O & O & O & 0 & su!ejunow чұешету ' $\varepsilon$ \\
\hline & O & O & & $\mathrm{C}$ & O & O & $\mathrm{O}$ & O & $\mathrm{O}$ & O & Ч¥!|ОЧРеg очерІ 'Z \\
\hline & & & & O & O & 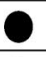 & 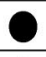 & & & & eıә|!pıoว ue!peueว uıəutnos 'al \\
\hline & & & O & O & O & $\bigcirc$ & 0 & & & & 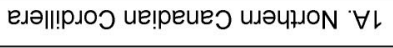 \\
\hline
\end{tabular}
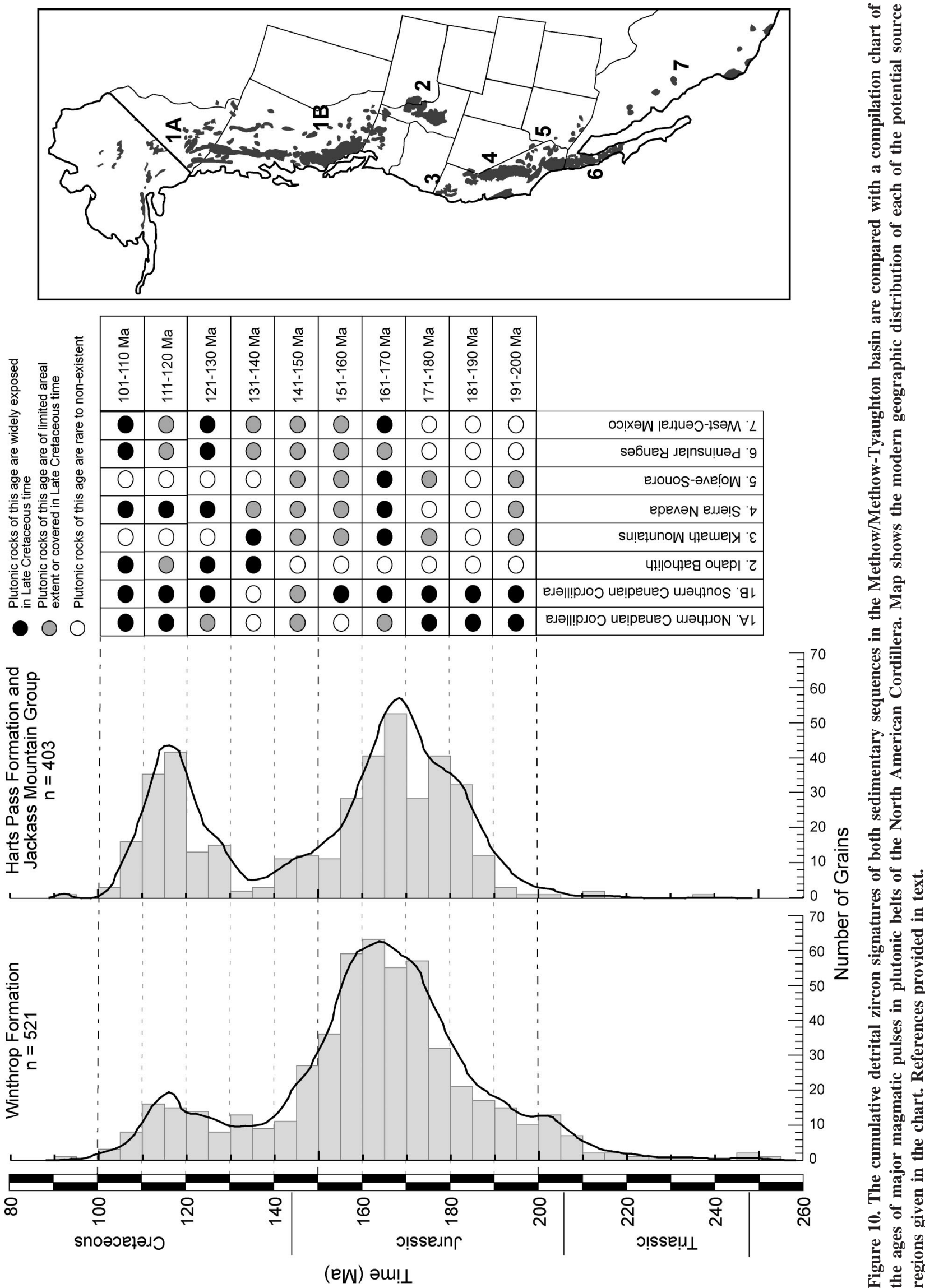


\section{Constraints on Potential Source Regions}

The most likely sources of detrital zircon grains in the Methow/Methow-Tyaughton strata are the plutonic igneous rocks within the source region, given the morphology, internal zoning characteristics, and abundance of the detrital zircon grains. The grains are large (generally 100-300 $\mu \mathrm{m}$ ), show no visual evidence of older cores, and often show welldeveloped oscillatory zoning characteristic of magmatic growth (Hanchar and Miller, 1993). Moreover, the majority of detrital zircon is derived from felsic to intermediate plutonic rocks; smaller contributions come from crystalline metamorphic assemblages and recycled clastic sedimentary successions (Gehrels, 2000). Therefore, we restricted our provenance search to regions containing plutonic rocks with ages that match the detrital zircon pattern identified in the sedimentary succession and that likely were exposed during deposition of the Harts Pass Formation/Jackass Mountain Group and the Winthrop Formation in middle to Late Cretaceous time. The probability of exposure was assessed by a variety of means, such as the existence of Late Cretaceous unconformities (e.g., southern and northern Canadian Cordillera, Idaho, westcentral Mexico), age and provenance relationships with adjacent basinal strata (e.g., Sierra Nevada and Baja California), and uplift ages (e.g., northern Cordillera, Baja California).

Sedimentologic, structural, and geochemical considerations allow further limits to be placed on the search for potential source terranes. Sedimentary petrology indicates that the Jackass Mountain Group and Winthrop Formation constitute a volcano-plutonic unroofing succession (Coates, 1974; Kleinspehn, 1985). Abundant west-directed paleocurrent indicators demonstrate that the Harts Pass Formation/Jackass Mountain Group and Winthrop Formation were derived from an eastern highland (Cole, 1973; Coates, 1974; Tennyson and Cole, 1978; Kleinspehn, 1985; Kiessling, 1998). Paleomagnetic data limit vertical axis rotations to less than $90^{\circ}$ within Pasayten Group strata, consistent with an eastern source for these strata (Enkin et al., 2003). Neodymium isotope data from the Jackass Mountain Group and shale and sandstone intervals within units in the northern Methow terrane correlative with the Harts Pass Formation/Jackass Mountain Group indicate a source region dominated by essentially juvenile crust with a minor component of evolved materials, such as a fringing continental volcanic arc succession (Mahoney, 1994). Combined with stratigraphic information and the detrital zircon signatures, these disparate data indicate that
Methow strata were deposited in a forearc position west of a dissected juvenile volcanic arc assemblage characterized by a wide variety of primarily Early Jurassic to Early Cretaceous plutons and east of an emergent fold-andthrust system that incorporated ocean-floor detritus. We concentrate this analysis on potential source regions along the length of the western North American Cordilleran margin (Fig. 10), although it is possible that the Methow/Methow-Tyaughton basin developed adjacent to an unknown crustal entity unassociated with North America.

\section{Potential Source Regions}

Canadian Cordillera. The Canadian Cordillera is a mosaic of allochthonous tectonostratigraphic terranes juxtaposed along regional fault systems and intruded by Jurassic to Tertiary plutons (e.g., Coney et al., 1980). These terranes can be broadly grouped into two superterranes separated by a major zone of middle Cretaceous to Tertiary contractional deformation (Monger et al., 1982; Rubin et al., 1990; Monger, 1991; Monger and Journeay, 1994). The Intermontane superterrane (Stikinia, Cache Creek, Yukon-Tanana, and Quesnellia terranes; Fig. 1) accreted to the western margin of North America by Middle Jurassic time (Monger et al., 1982; Monger, 1991; Monger and Journeay, 1994); the Insular superterrane (Wrangellia and Alexander terranes; Fig. 1) accreted to the western margin of North America by at least the middle Cretaceous (Monger et al., 1982; Rubin et al., 1990). Because stratigraphic, structural, and paleomagnetic constraints preclude the Insular superterrane as a potential source, only the Intermontane superterrane is discussed here.

Northern Canadian Cordillera (northern British Columbia, Yukon, Alaska). The Intermontane superterrane in the northern Canadian Cordillera includes Triassic to Jurassic volcanic arc rocks of the Stikinia terrane and upper Proterozoic to Paleozoic continentalmargin metasedimentary rocks of the YukonTanana terrane (Monger et al., 1982; Mortensen, 1992). These rocks are intruded by extensive Late Triassic to Early Jurassic (214$180 \mathrm{Ma}$ ) plutonic rocks with a minor component of Middle to Late Jurassic (160-140 Ma) plutons; these intrusions were followed by widespread plutonism in middle Cretaceous time (110-90 Ma; Armstrong, 1988).

Southern Canadian Cordillera (southern British Columbia and northern Washington). The southern Canadian Cordillera includes Mississippian to Jurassic oceanic mélange of the Cache Creek terrane, Triassic to Jurassic volcanic arc assemblages of Quesnellia, late Paleozoic oceanic rocks of the Slide Mountain terrane, and pericratonic rocks of the Kootenay terrane (Monger et al., 1982). These terranes are intruded by an extensive suite of Late Triassic to early Tertiary plutonic rocks; major pulses of magmatism occurred in Late Triassic-Early Jurassic (210-187 Ma), Middle to Late Jurassic (180-148 Ma), and middle to Late Cretaceous (130-85 Ma) time (Armstrong et al., 1988; Greig et al., 1992; Woodsworth et al., 1992; Ghosh et al., 1995).

Idaho batholith. The Idaho batholith is primarily a Late Cretaceous (90-75 Ma) intrusive complex with older phases (up to 120 Ma) along its western and northwestern margins (Lewis et al., 1987). The batholith was emplaced into an imbricated succession of Precambrian to Paleozoic sedimentary rocks of cratonal affinity (Armstrong et al., 1977; Fleck, 1990). The Salmon River shear zone forms the western margin of the Idaho batholith and separates rocks of the continental margin from accreted terranes of the Blue Mountains province (Avé Lallemant, 1995). The Blue Mountains province consists of four major allochthonous terranes containing magmatic rocks of Permian to Triassic age. At least four episodes of metamorphism at 130, 118, 109, and $101 \mathrm{Ma}$ record accretion of these terranes along the Salmon River shear zone; minor associated plutonism was most extensive at ca. 115 Ma (Snee et al., 1995).

Klamath Mountains. The Klamath Mountains consist of a series of terranes representing a Permian-Triassic subduction complex that developed west of a Permian-Triassic arc system (e.g., Irwin, 1981; Saleeby et al., 1992). These terranes were structurally imbricated by a major east-dipping thrust system and overprinted by arc-related magmatism (Burchfiel et al., 1992; Saleeby et al., 1992). Volcanism and plutonism in the Klamath Mountains occurred in distinct periods during the Early Jurassic (ca. 200 Ma), early Middle Jurassic (177-167 Ma), Late Jurassic (ca. 155 $\mathrm{Ma}$ ), and latest Jurassic to Early Cretaceous (150-135 Ma; Hacker et al., 1995; Irwin and Wooden, 1999, and references therein).

Sierra Nevada. The Sierra Nevada magmatic system is isotopically and structurally linked to the North American craton (Kistler and Peterman, 1973; Saleeby et al., 1987, 1989; Linn et al., 1992). The Sierran batholithic belt consists of autochthonous plutons that intruded the North American margin in Jurassic and Cretaceous time (e.g., Evernden and Kistler, 1970; Stern et al., 1981; Bateman, 1983; Saleeby et al., 1989). The batholith intrudes Paleozoic miogeoclinal strata on its 
eastern margin and a complex assemblage of Paleozoic arc-related terranes and subduction complexes on its northwestern margin. Plutons in the northwestern part of the batholithic belt range in age from ca. 170 to $130 \mathrm{Ma}$, and those in the southern and eastern parts of the system range in age from 125 to $75 \mathrm{Ma}$ (Irwin and Wooden, 2001, and references therein).

Mojave-Sonora region. The Mojave-Sonora region lies at the junction of several Proterozoic crustal provinces that are overlain by a relatively thin veneer of Cambrian to Triassic miogeoclinal strata (e.g., Wooden and Miller, 1990). Widespread plutonism, metamorphism, and thin- to thick-skinned thrust faulting disrupted these cratonal rocks in early Middle Jurassic time, and plutonic ages of ca. 175-160 Ma are common (Tosdal et al., 1989; Miller et al., 1990; Howard et al., 1995). Middle Jurassic magmatism culminated with emplacement of the Independence dike swarm at ca. 148 Ma (Tosdal et al., 1989). Widespread crustal extension, denudation of the arc succession, and deposition of coarse clastic strata in isolated rift and wrench-fault basins began in Late Jurassic time, and magmatic rocks of Early and early Late Cretaceous are rare. In latest Cretaceous to Eocene time, the SonoraMojave region was the site of widespread tectonism and metamorphism; magmatism began at ca. $92 \mathrm{Ma}$ (Barth et al., 2001).

Peninsular Ranges. The Peninsular Ranges batholith is divided longitudinally into distinct western and eastern zones on the basis of age, petrology, style, and depth of emplacement, prebatholithic wall rock, and geophysical parameters (Gastil, 1975; Gromet and Silver, 1987; Silver and Chappell, 1988; Todd et al., 1988). Western zone intrusions are older (ca. 140 to $105 \mathrm{Ma}$ ), range from gabbro to monzogranite in composition, and have relatively primitive island-arc geochemical affinities (Silver and Chappell, 1988). The eastern zone of the Peninsular Ranges batholith is dominated by large volumes of relatively homogeneous tonalite and low-K granodiorite ranging from 105 to $80 \mathrm{Ma}$ (Gromet and Silver, 1987; Silver and Chappell, 1988; Walawender et al., 1990).

West-central Mexico. The Sierra Madre Occidental, one of the largest Tertiary volcanic provinces in the world, overlies Precambrian crystalline basement and miogeoclinal rocks at its north end and accreted rocks of the Guerrero composite terrane in the south (de Cserna, 1989). The Upper Jurassic to Lower Cretaceous (Tithonian to Albian) island-arc volcanic rocks and associated mélange (metamorphosed siliciclastic turbidites, mid-oceanic-ridge basalts, limestone, shale) that make up the Guerrero composite terrane are intruded by Middle Jurassic plutons (ca. 162-157 Ma; Iriondo, 2001). During the Cretaceous, nuclear Mexico was covered by a carbonate platform, and the Guerrero composite terrane was characterized by arc volcanism (de Cserna, 1989). U-Pb geochronologic data for plutonic rocks are sparse in west-central Mexico, and the vast majority of $\mathrm{Rb}-\mathrm{Sr}$ and $\mathrm{K}-\mathrm{Ar}$ dates are on Late Cretaceous to early Tertiary plutonic rocks associated with the Laramide orogenic event (Iriondo, 2001).

\section{Best-Match Comparison}

Figure 10 provides a comparison of the composite detrital zircon age signature of Methow/Methow-Tyaughton strata with the potential Cordilleran source regions just described to assess the likelihood of any region being the primary source of detritus into the sedimentary basin during middle to Late Cretaceous time. Potential sources of error in this comparison include the difficulty in determining what rocks were exposed in middle to Late Cretaceous time and the uncertainty associated with any individual age analysis within the proposed source area. This comparison is presented as a means of finding the best match for the Methow/Methow-Tyaughton detrital zircon age pattern; this pattern-matching analysis is not intended to be a rigorous assessment of the exact age distribution in any given source region. Detailed analysis of the Mesozoic magmatic evolution of each region is beyond the scope of this investigation.

Cretaceous strata of the Methow/MethowTyaughton basin are characterized by Mesozoic detrital zircon ages ranging from Late Triassic to middle Cretaceous (ca. 220-100 $\mathrm{Ma}$ ); the age distribution shows a major Middle to Late Jurassic peak (ca. 180-150 Ma) and a smaller Cretaceous peak (ca. 120-110 Ma; Fig. 10). The southern Canadian Cordillera provides the strongest probable match to this age spectrum, as that area contains abundant Early and Middle Jurassic and Early Cretaceous rocks and smaller volumes of every other major detrital-grain population found in rocks of the Methow/Methow-Tyaughton basin. In fact, the absence of abundant 150-180 Ma plutons in the Northern Canadian Cordillera, Idaho batholith, Sierra Nevada, Peninsular Ranges, and west-central Mexico and the absence of 120-110 Ma plutons in the Klamath Mountains and the Mojave-Sonora region leave the Southern Canadian Cordillera as the only source region identified along the Cordilleran margin that contains ages which make up the two major age peaks in the detrital zircon signature of the Methow/Methow-
Tyaughton strata (Fig. 10). In addition, Late Triassic and Early Jurassic ages, which are common in the Canadian Cordillera, are particularly sparse in other regions.

The Methow detrital zircon results strongly support a linkage between the Methow terrane and source regions to the east in the southern Canadian Cordillera. This linkage has been suggested by earlier workers (e.g., Dickinson, 1976; O'Brien et al., 1992) and is supported by the existence of Archean detrital zircons in both the overlying Methow/Methow-Tyaughton strata and in the associated Nanaimo basin (Mahoney et al., 1999). These results are problematic for large-scale displacement models that require $\sim 2800 \mathrm{~km}$ northward translation of the Methow terrane between ca. 85 and $50 \mathrm{Ma}$, as there is no known source region to the south that could have provided the necessary detrital zircon grains to the Methow/ Methow-Tyaughton basin during middle to Late Cretaceous time.

\section{CONCLUSIONS}

The results of the high-resolution sampling utilized in this study of the Methow/MethowTyaughton basin provide a useful basis for establishing detrital zircon sampling protocols for provenance analysis of similar basins. Following the sampling scale hierarchy established by Ingersoll et al. (1993) for petrofacies models, the higher the basin order, the more homogeneous and well-mixed the sediment and therefore the lower the sampling density required to characterize detrital zircon age distributions. Although the overall detrital zircon age distributions for both the second-order Harts Pass/Jackass Mountain Group and the first- to second-order Winthrop Formation can be broadly characterized with relatively few samples, both successions display significant heterogeneity.

Even within the same scale of system, depositional environment strongly influences the nature and extent of heterogeneity in the detrital zircon age distributions. Although both successions display heterogeneity, the variability in the deep-water turbidite deposits of the Harts Pass Formation is systematic and predictable; in contrast, the fluvial and marginalmarine deposits of the Winthrop Formation have heterogeneous detrital zircon age distributions that vary unpredictably from sample to sample. These results suggest that highresolution detrital zircon analysis does permit fine-scale interpretation within a turbiditic sedimentary succession, such as the Harts Pass Formation, but heterogeneity within fluvial systems like the Winthrop Formation is 
too large and unpredictable to permit accurate fine-scale characterization of the evolution of source regions with a reasonable number of samples.

The combined detrital zircon age signatures of the Methow/Methow-Tyaughton basin include every age population present in both the Harts Pass Formation/Jackass Mountain Group and the Winthrop Formation. Compared with potential source regions throughout the North American Cordillera, the basin's detrital zircon signature matches best with source regions in the southern Canadian Cordillera. This provenance link provides evidence against large-scale dextral translation of the Methow terrane and overlying JurassicCretaceous strata away from a southern source region and suggests that the Methow/MethowTyaughton basin developed in close proximity to the southern Canadian Cordillera.

\section{APPENDIX. LABORATORY TECHNIQUES}

Zircon separation procedures were as follows: rock sample was crushed and powdered by using jaw crusher and disk grinder; powdered sample was run through Gemeni table to remove the light fraction; remaining sample soaked in $10 \%$ acetic acid until no reaction took place; sample was washed and then soaked in $10 \%$ hydrogen peroxide until no reaction took place; sample was washed, dried, and sieved through 48 mesh; sieved sample was run through vertical Franz to remove iron filings and most mafic minerals; nonmagnetic fraction placed in lithium metatungstate (LMT) with density of 2.96 $\mathrm{g} / \mathrm{cm}^{3}$ to remove lighter fraction; remaining heavy fraction run through slope Franz to remove remaining mafic minerals. The settings for the slope Franz were $10^{\circ}$ at $0.5 \mathrm{~A}, 10^{\circ}$ at $1.0 \mathrm{~A}$, and $10^{\circ}$ at $1.8 \mathrm{~A}$, following Sircombe and Stern (2002). We analyzed several of the zircon grains recovered from the final magnetic fractions of four samples to test for potential separation bias introduced by the slightly variable magnetic susceptibility of zircon. The ages of these slightly magnetic zircons were consistent with ages from the nonmagnetic fraction, indicating that the magnetic separation procedure did not introduce a bias in the detrital zircon population. The nonmagnetic slope Franz split was placed in methylene iodide (MEI) with density of $3.3 \mathrm{~g} / \mathrm{cm}^{3}$; part of the heavy MEI split (mostly zircon grains) was spread out on a microscope slide; a small area of the slide was cleared of all zircon grains and those zircon grains (representative of the entire sample) were mounted in epoxy for analysis by SHRIMPRG (sensitive, high-resolution ion microprobereverse geometry).

For U-Pb analyses using the SHRIMP-RG at the Stanford-U.S. Geological Survey Micro-isotopic Analytical Center (SUMAC), the intensity of the $\mathrm{O}_{2}^{-}$primary beam was 6-10 nA, mass resolution was $6500-7500$ at $10 \%$ peak height, and sensitivity was 5-15 counts per second per $1 \mathrm{nA}$ per $1 \mathrm{ppm}$ $\mathrm{Pb}$ in SL13 concentration standard. The primary beam spot size was $20-40 \mu \mathrm{m}$ in diameter, and the spot was placed as close as possible to the core of each grain, avoiding cracks and inclusions and recognizing that many grains are fragments. The operator worked systematically through the array of grains mounted in epoxy, thereby avoiding potential bias introduced by selecting grains for analysis. Each analysis consisted of five scans through each isotope mass, counting $2 \mathrm{~s}$ on $\mathrm{Zr}_{2} \mathrm{O}, 7 \mathrm{~s}$ on ${ }^{204} \mathrm{~Pb}, 7$ $\mathrm{s}$ on background, $12 \mathrm{~s}$ on ${ }^{206} \mathrm{~Pb}, 16 \mathrm{~s}$ on ${ }^{207} \mathrm{~Pb}, 10 \mathrm{~s}$ on ${ }^{208} \mathrm{~Pb}, 5 \mathrm{~s}$ on ${ }^{238} \mathrm{U}, 3 \mathrm{~s}$ on ${ }^{248}(\mathrm{ThO})$, and $3 \mathrm{~s}$ on ${ }^{254}(\mathrm{UO})$.

\section{ACKNOWLEDGMENTS}

We thank Ralph Haugerud for providing field maps, valuable assistance in the field, and helpful comments on the manuscript. We thank Paul Link for useful discussions, and Peter Mustard, James Haggart, and Stephan Graham for helpful comments and suggestions that greatly improved this manuscript. David Kimbrough, Elena Centeno-Garcia, W. Porter Irwin, and James Mortenson were of great assistance in compiling pluton ages for the North American Cordillera. We are grateful to the SUMAC laboratory personnel for assistance with sample preparation and data collection and reduction. We thank George Gehrels, Keith Sircombe, and Gerald Ross for their thoughtful reviews of the manuscript. This research was funded by a Geological Society of America student research grant, Stanford University McGee Grants, Stanford University Shell Fund grants, an American Association of Petroleum Geologists Grant-In-Aid, and National Science Foundation Grant EAR-0001036.

\section{REFERENCES CITED}

Armstrong, R.L., 1988, Mesozoic and early Cenozoic magmatic evolution of the Canadian Cordillera, in Clark, S.P., Jr., Burchfiel, B.C., and Suppe, J., eds., Processes in continental lithospheric deformation: Geological Society of America Special Paper 218, p. 55-91.

Armstrong, R.L., Taubeneck, W.H., and Hales, P.O., 1977, $\mathrm{Rb}-\mathrm{Sr}$ and K-Ar geochronometry of Mesozoic granitic rocks and their $\mathrm{Sr}$ isotopic composition, Oregon, Washington, and Idaho: Geological Society of America Bulletin, v. 88, p. 397-411.

Ave Lallemant, H.G., 1995, Pre-Cretaceous tectonic evolution of the Blue Mountains province, northeastern Oregon, in Vallier, T.L., and Brooks, H.C., eds., Petrology and tectonic evolution of pre-Tertiary rocks of the Blue Mountains region: U.S. Geological Survey Professional Paper P1438, p. 271-304

Barksdale, J.D., 1975, Geology of the Methow Valley, Okanogan County, Washington: Washington Division of Geology and Earth Resources Bulletin, v. 68, p. 72.

Barth, A.P., Jacobsen, C.E., Coleman, D.S., and Wooden, J.L., 2001, Construction and tectonic evolution of Cordilleran continental crust: Examples from the San Gabriel and San Bernardino Mountains, in Dunne, G., and Cooper, J., eds., Geologic excursions in the California deserts and adjacent Transverse Ranges: Los Angeles, Pacific Section, Society of Economic Paleontologists and Mineralogists, p. 17-53.

Bateman, P.C., 1983, A summary of critical relations in the central part of the Sierra Nevada batholith, California, U.S.A., in Roddick, J.A., ed., Circum-Pacific plutonic terranes: Geological Society of America Memoir, v. 159 , p. $241-254$.

Beck, M.E., Jr., Burmester, R.F., and Schoonover, R., 1981, Paleomagnetism and tectonics of the Cretaceous Mt. Stuart batholith of Washington: Translation or tilt?: Earth and Planetary Science Letters, v. 56, p. $336-342$

Berry, R.F., Jenner, G.A., Meffre, S., and Tubrett, M.N., 2001, A North American provenance for Neoproterozoic to Cambrian sandstones in Tasmania?: Earth and Planetary Science Letters, v. 192, p. 207-222.

Bunning, B.B., 1990, Geologic map of the east half of the Twisp 1:100,000 Quadrangle, Washington: Washing- ton State Division of Geology and Earth Resources Open-File Report 90-9, 1 sheet, 51 p.

Burchfiel, B.C., Cowan, D.S., and Davis, G.A., 1992, Tectonic overview of the Cordilleran orogen in the Western United States, in Burchfiel, B.C., Lipman, P.W. and Zoback, M.L., eds., The Cordilleran orogen: Coterminous U.S.: Boulder, Colorado, Geological Society of America, Geology of North America, v. G-3, p. 407-479.

Butler, R.F., Gehrels, G.E., McClelland, W.C., May, S.R., and Klepacki, D., 1989, Discordant paleomagnetic poles from the Canadian Coast Plutonic Complex: Regional tilt rather than large-scale displacement?: Geology, v. 17, p. 691-694.

Coates, J.A., 1974, Geology of the Manning Park area, British Columbia: Geological Survey of Canada Bulletin, v. $238,177 \mathrm{p}$.

Cole, M.R., 1973, Petrology and dispersal patterns of Jurassic and Cretaceous sedimentary rocks in the Methow river area, North Cascades, Washington [Ph.D. thesis]: Seattle, University of Washington, $110 \mathrm{p}$

Coney, P.J., Jones, D.L., and Monger, J.W.H., 1980, Cordilleran suspect terranes: Nature, v. 288, p. 329-333.

Cumming, G.L., and Richards, J.R., 1975, Ore lead isotope ratios in a continuously changing Earth: Earth and Planetary Science Letters, v. 28, p. 155-171.

de Cserna, Z., 1989, An outline of the geology of Mexico, in Bally, A.W., and Palmer, A.R., eds., The geology of North America-An overview: Boulder, Colorado, Geological Society of America, Geology of North America, v. A, p. 233-264.

DeGraaff-Surpless, K., Graham, S.A., Wooden, J.L., and McWilliams, M.O., 2002, Detrital zircon provenance analysis of the Great Valley Group, California: Evolution of an arc-forearc system: Geological Society of America Bulletin, v. 114 , p. $1564-1580$

Dickinson, W.R., 1976, Sedimentary basins developed during evolution of Mesozoic-Cenozoic arc-trench system in western North America: Canadian Journal of Earth Sciences, v. 13, p. 1268-1287.

Dickinson, W.R., and Gehrels, G.E., 2000, Sandstone petrofacies of detrital zircon samples from Paleozoic and Triassic strata in suspect terranes of northern Nevada and California, in Soreghan, M.J., and Gehrels, G.E., eds., Paleozoic and Triassic paleogeography and tectonics of western Nevada and northern California: Geological Society of America Special Paper 347, p. $151-171$.

Dodson, M.H., Compston, W., Williams, I.S., and Wilson, J.F., 1988, A search for ancient detrital zircons in Zimbabwean sediments: Geological Society [London] Journal, v. 145, p. 977-983.

Dragovich, J.D., and Norman, D.K., 1995, Geologic map of the west half of the Twisp 1:100,000 Quadrangle, Washington: Washington State Division of Geology and Earth Resources Open-File Report 95-3, 63 p.

Enkin, R.J., Mahoney, J.B., Baker, J., Kiessling, M., and Haugerud, R., 2003, Syntectonic remagnetization in the southern Methow block: Resolving large displacements in the southern Canadian Cordillera: Tectonics (in press).

Evernden, J.F., and Kistler, R.W., 1970, Chronology of emplacement of Mesozoic batholithic complexes in California and western Nevada: U.S. Geological Survey Professional Paper 623, $42 \mathrm{p}$

Fleck, R.J., 1990, Neodymium, strontium, and trace element evidence of crustal anatexis and magma mixing in the Idaho batholith, in Anderson, J.L., ed., The nature and origin of Cordilleran magmatism: Geological Society of America Memoir 174, p. 359-373.

Galloway, W.E., and Williams, T.A., 1991, Sediment accumulation rates in time and space: Paleogene genetic stratigraphic sequences of the northwestern Gulf of Mexico basin: Geology, v. 19, p. 986-989.

Garver, J.I., 1992, Provenance of Albian-Cenomanian rocks of the Methow and Tyaughton basins, southern British Columbia: A mid-Cretaceous link between North America and the Insular terrane: Canadian Journal of Earth Sciences, v. 29, p. 1274-1295.

Gastil, R.G., 1975, Plutonic zones in the Peninsular Ranges of southern California and northern Baja California: Geology, v. 3, p. 361-363. 
Gehrels, G.E., 2000, Introduction to detrital zircon studies of Paleozoic and Triassic strata in western Nevada and northern California, in Soreghan, M.J., and Gehrels, G.E., eds., Paleozoic and Triassic paleogeography and tectonics of western Nevada and northern California: Geological Society of America Special Paper 347, p. 1-18.

Gehrels, G.E., and Dickinson, W.R., 1995, Detrital zircon provenance of Cambrian to Triassic miogeoclinal and eugeoclinal strata in Nevada: American Journal of Science, v. 295 , p. $18-48$.

Gehrels, G.E., Dickinson, W.R., Ross, G.M., Stewart, J.H., Howell, D.G., 1995, Detrital zircon reference for Cambrian to Triassic miogeoclinal strata of western North America: Geology, v. 23, p. 831-834.

Ghosh, D.K., and Lambert, R.S.J., 1995, Nd-Sr isotope geochemistry and petrogenesis of Jurassic granitoid intrusives, southeast British Columbia, Canada, in Miller, D.M., and Busby, C.J., eds., Jurassic magmatism and tectonics of the North American Cordillera: Geological Society of America Special Paper, v. 299, p. $141-157$.

Greig, C.J., Armstrong, R.L., Harakal, J.E., Runkle, D., and Van Der Heyden, P., 1992, Geochronometry of the Eagle Plutonic Complex and the Coquihalla area, southwestern British Columbia: Canadian Journal of Earth Sciences, v. 29, p. 812-829.

Gromet, L.P., and Silver, L.T., 1987, REE variations across the Peninsular Ranges batholith: Implications for batholithic petrogenesis and crustal growth in magmatic arcs: Journal of Petrology, v. 28, p. 75-125.

Hacker, B.R., Donato, M.M., Barnes, C.G., McWilliams, M.O., and Ernst, W.G., 1995, Timescales of orogeny: Jurassic construction of the Klamath Mountains: Tectonics, v. 14, p. 677-703.

Hanchar, J.M., and Miller, C.F., 1993, Zircon zonation patterns as revealed by cathodoluminescence and backscattered electron images: Implications for interpretation of complex crustal histories: Chemical Geology, v. 110 , p. $1-13$.

Haugerud, R.A., Mahoney, J.B., and Dragovitch, J.D., 1996, Geology of the Methow block: Northwest Geological Society, Fall Field Trip, Guidebook: Seattle, Washington, Northwest Geological Society, 37 p.

Howard, K.A., McCaffrey, K.J.W., Wooden, J.L., Foster, D.A., and Shaw, S.E., 1995, Jurassic thrusting of Precambrian basement over Paleozoic cover in the Clipper Mountains, southeastern California, in Miller, D.M., and Busby, C., eds., Jurassic magmatism and tectonics of the North American Cordillera: Geological Society of America Special Paper 299, p. 375-392.

Hurlow, H.A., 1993, Mid-Cretaceous strike-slip and contractional fault zones in the western intermontane terrane, Washington, and their relation to the North Cascades-southeastern Coast Belt orogen: Tectonics, v. 12 , p. $1240-1257$.

Ingersoll, R.V., 1983, Petrofacies and provenance of late Mesozoic forearc basin, northern and central California: American Association of Petroleum Geologists Bulletin, v. 67, p. $1125-1142$.

Ingersoll, R.V., 1990, Actualistic sandstone petrofacies: Discriminating modern and ancient source rocks: Geology, v. 18, p. 733-736

Ingersoll, R.V., Kretchmer, A.G., and Valles, P.K., 1993, The effect of sampling scale on actualistic sandstone petrofacies: Sedimentology, v. 40, p. 937-953.

Iriondo, A., 2001, Proterozoic basements and their Laramide juxtaposition in NW Sonora, Mexico: Tectonic constraints on the SW margin of Laurentia [Ph.D. thesis]: Boulder, University of Colorado, $222 \mathrm{p}$.

Irving, E., Wynne, P.J., Thorkelson, D.J., and Schiarizza, P., 1996, Large (1000 to $4000 \mathrm{~km}$ ) northward movements of tectonic domains in the northern Cordillera, 83 to 45 Ma: Journal of Geophysical Research, v. 101, p. $17,901-17,916$

Irwin, W.P., 1981, Tectonic accretion of the Klamath Mountains, in Ernst, W.G., ed., The geotectonic evolution of California (Rubey Volume I): Englewood Cliffs, New Jersey, Prentice-Hall, p. 29-49.

Irwin, W.P., and Wooden, J.L., 1999, Plutons and accretionary episodes of the Klamath Mountains, California and Oregon: U.S. Geological Survey Open-File Report 99-0374, 1 sheet.

Irwin, W.P., and Wooden, J.L., 2001, Map showing plutons and accreted terranes of the Sierra Nevada, California, with a tabulation of U/Pb isotopic ages: U.S. Geological Survey Open-File Report 01-0229, 1 sheet.

Journeay, J.M., and Friedman, R.M., 1993, The Coast Belt thrust system: Evidence of Late Cretaceous shortening in southwest British Columbia: Tectonics, v. 3, p. 756-775.

Kiessling, M.D., 1998, Provenance and stratigraphic correlation of the mid-Cretaceous Pasayten Group, northern Washington and Manning Provincial Park, British Columbia [M.S. thesis]: Pocatello, Idaho State University, $118 \mathrm{p}$.

Kiessling, M.A., and Mahoney, J.B., 1997, Revised stratigraphy of the Pasayten Group, Manning Park, British Columbia: Geological Survey of Canada, Current Research, v. 1997-A/B, p. 151-158.

Kistler, R.W., and Peterman, Z.E., 1973, Variations in Sr, $\mathrm{Rb}, \mathrm{K}, \mathrm{Na}$, and initial ${ }^{87} \mathrm{Sr} /{ }^{86} \mathrm{Sr}$ in Mesozoic granitic rocks and intruded wall rocks in central California: Geological Society of America Bulletin, v. 84, p. 3489-3512.

Kleinspehn, K.L., 1985, Cretaceous sedimentation and tectonics, Tyaughton-Methow Basin, southwestern British Columbia: Canadian Journal of Earth Sciences, v. 22 , p. $154-174$

Kodama, K.P., and Ward, P.D., 2001, Compaction-corrected paleomagnetic paleolatitudes for Late Cretaceous rudists along the Cretaceous California margin: Evidence for less than $1500 \mathrm{~km}$ of post-Late Cretaceous offset for Baja British Columbia: Geological Society of America Bulletin, v. 113, p. 1171-1178.

Lewis, R.S., Kiilsgaard, T.H., Bennett, E.H., and Hall, W.E., 1987, Lithologic and chemical characteristics of the central and southeastern part of the southern lobe of the Idaho batholith, in Brooks, H.C., and Vallier, T.L., eds., Geology of the Blue Mountains region of Oregon, Idaho, and Washington: The Idaho batholith and its border zone: U.S. Geological Survey Professional Paper 1437, p. 171-196.

Linn, A.M., DePaolo, D.J., and Ingersoll, R.V., 1992, Nd$\mathrm{Sr}$ isotopic, geochemical, and petrographic stratigraphy and paleotectonic analysis: Mesozoic Great Valley forearc sedimentary rocks of California: Geological Society of America Bulletin, v. 104, p. 1264-1279.

Mahoney, J.B., 1994, Nd isotopic signatures and stratigraphic correlations: Examples from western Pacific marginal basins and Middle Jurassic rocks of the southern Canadian Cordillera [Ph.D. thesis]: Vancouver, University of British Columbia, $328 \mathrm{p}$.

Mahoney, J.B., and Journeay, J.M., 1993, The Cayoosh Assemblage, southwestern British Columbia: Last vestige of the Bridge River Ocean: Geological Survey of Canada Paper 93-1A, p. 235-244.

Mahoney, J.B., Mustard, P.S., Haggart, J.W., Friedman, R.M., Fanning, C.M., and McNicoll, V.J., 1999, Archean zircons in Cretaceous strata of the western Canadian Cordillera: The "Baja B.C." hypothesis fails a "crucial test": Geology, v. 27, p. 195-198.

Miller, C.F., Wooden, J.L., Bennett, V.C., Wright, J.E., Solomon, G.C., and Hurst, R.W., 1990, Petrogenesis of the composite peraluminous-metaluminous Old-Woman-Piute Range batholith, southeastern California: Isotopic constraints, in Anderson, J.L., ed., The nature and origin of Cordilleran magmatism: Geological Society of America Memoir 174, p. 99-109.

Miller, R.B., Mattinson, J.M., Goetsch Funk, S.A., Hopson, C.A., Treat, C.L., and McDougall, K.A., 1993, Tectonic evolution of Mesozoic rocks in the southern and central Washington Cascades, in Dunne, G.C., and McDougall, K.A., eds., Mesozoic paleogeography of the Western United States, Volume II: Los Angeles, Pacific Section, Society of Economic Paleontologists and Mineralogists, p. 81-98.

Monger, J.W.H., 1991, The geology of the Canadian Cordillera, in Smith, P.L., ed., Field guide to the paleontology of southwestern Canada: Vancouver, British Columbia, Geological Association of Canada, p. 6-18.

Monger, J.W.H., and Journeay, J.M., 1994, Guide to the geology and tectonic evolution of the southern Coast
Mountains: Geological Survey of Canada Open-File Report 2490, $77 \mathrm{p}$.

Monger, J.W.H., Price, R.A., and Templeman-Kluit, D.J., 1982, Tectonic accretion and the origin of the two major metamorphic welts in the Canadian Cordillera: Geology, v. 10 , p. $70-75$

Mortensen, J.K., 1992, Pre-mid-Mesozoic tectonic evolution of the Yukon-Tanana terrane, Yukon and Alaska: Tectonics, v. 11, p. 836-853.

O’Brien, J.A., Gehrels, G.E., and Monger, J.H.W., 1992, U$\mathrm{Pb}$ geochronology of plutonic clasts from conglomerates in the Ladner and Jackass Mountain groups and the Peninsula Formation, southwestern British Columbia, in Current Research, Part A: Geological Survey of Canada Paper 92-1A, p. 209-214.

Paces, J.B., and Miller, J.D., Jr., 1993, Precise U-Pb ages of Duluth Complex and related mafic intrusions, northeastern Minnesota: Geochronological insight into physical, petrogenetic, paleomagnetic, and tectonomagnetic processes associated with the $1.1 \mathrm{Ga}$ midcontinental rift system: Journal of Geophysical Research, v. 98, p. 13,997-14,013.

Press, W.H., Flannery, B.P., Teukolsky, S.A., and Vetterling, W.T., 1986, Numerical recipes, The art of scientific computing: Cambridge, Cambridge University Press, $186 \mathrm{p}$.

Ross, G.M., and Bowring, S.A., 1990, Detrital zircon geochronology of the Windermere Supergroup and the tectonic assembly of the southern Canadian Cordillera: Journal of Geology, v. 98, p. 879-893.

Rubin, C.M., Saleeby, J.B., Cowan, D.S., Brandon, M.T. and McGroder, M.F., 1990, Regionally extensive midCretaceous west-vergent thrust system in the north western Cordillera: Implications for continent-margin tectonism: Geology, v. 18, p. 276-280.

Saleeby, J.B., Sams, D.B., and Kistler, R.W., 1987, U/Pb zircon, strontium, and oxygen isotopic and geochronological study of the southernmost Sierra Nevada batholith, California: Journal of Geophysical Research, v. 92 , p. 10433-10466.

Saleeby, J.B., Shaw, H.F., Niemeyer, S., Moores, E.M., and Edelman, S.H., 1989, U/Pb, Sm/Nd and $\mathrm{Rb} / \mathrm{Sr}$ geochronological and isotopic study of northern Sierr Nevada ophiolitic assemblages, California: Contributions to Mineralogy and Petrology, v. 102, p. $205-220$.

Saleeby, J.B., Busby-Spera, C., Oldow, J.S., Dunne, G.C., Wright, J.E., Cowan, D.S., Walker, N.W., and Allmendinger, R.W., 1992, Early Mesozoic tectonic evolution of the Western U.S., Cordillera, in Burchfiel, B.C. Lipman, P.W., and Zoback, M.L., eds., The Cordilleran orogen: Conterminous U.S.: Boulder, $\mathrm{CO}$, $\mathrm{Geo}^{-}$ logical Society of America, v. G-3, p. 107-168.

Schiarizza, P., and Payie, G., 1997, Geology of the Sitlika Assemblage in the Kenny Creek-Mount Olson area (93N/12, 13), central British Columbia in Lefebure, D.V., McMillan, W.J., and McArthur, J.G., eds., Geological fieldwork 1996: A summary of field activities and current research: Victoria, British Columbia, British Columbia Geological Division, Geological Fieldwork, Report 1997-1, p. 79-100.

Silver, L.T., and Chappell, B.W., 1988, The Peninsular Ranges batholith: An insight into the evolution of the Cordilleran batholiths of southwestern North America, in Brown, P.E., ed., The origin of granites: Transactions of the Royal Society of Edinburgh: Earth Sciences, v. 79, p. 105-121.

Sircombe, K.N., and Stern, R.A., 2002, An investigation of artificial biasing in detrital zircon U-Pb geochronology due to magnetic separation in sample preparation: Geochimica et Cosmochimica Acta, v. 66 p. 2379-2397.

Snee, L.W., Lund, K., Sutter, L.F., Balcer, D.E., and Evans, K.V., 1995, An ${ }^{40} \mathrm{Ar} /{ }^{39} \mathrm{Ar}$ chronicle of the tectonic development of the Salmon River suture zone, western Idaho, in Vallier, T.L., and Brooks, H.C., eds., Petrology and tectonic evolution of pre-Tertiary rocks of the Blue Mountains region: U.S. Geological Survey Professional Paper 1438, p. 359-414.

Stern, T.W., Bateman, P.C., Morgan, B.A., Newell, M.F., and Peck, D.L., 1981, Isotopic U-Pb ages of zircon from the granitoids of the central Sierra Nevada, Cal- 
ifornia: U.S. Geological Survey Professional Paper P1185,19 p.

Tabor, R.W., Haugerud, R.A., Booth, D.B., and Brown, E.H., 1994, Preliminary geologic map of the Mount Baker 30- by 60 -minute quadrangle, Washington: U.S. Geological Survey Open File Report 94-403, 43 p., 2 sheets.

Tennyson, M.E., and Cole, M.R., 1978, Tectonic significance of upper Mesozoic Methow-Pasayten Sequence, northeastern Cascade Range, Washington and British Columbia, in Howell, D.G., and McDougall, K., eds., Mesozoic paleogeography of the western United States: Los Angeles, Pacific Section, Society of Economic Paleontologists and Mineralogists Pacific Coast Paleogeography Symposium 2, p. 499-508.

Todd, V.R., Erskine, B.G., and Morton, D.M., 1988, Metamorphic and tectonic evolution of the northern Peninsular Ranges batholith, southern California, in Ernst, W.G., ed., Metamorphism and crustal evolution of the Western United States: Englewood Cliffs, New Jersey, Prentice-Hall, p. 894-937.

Tosdal, R.M., Haxel, G.B., and Wright, J.E., 1989, Jurassic geology of the Sonoran desert region, southern Arizona, southeastern California and northernmost Sonora: Construction of a continental margin magmatic arc, in Jenney, J.P., and Reynolds, S.J., eds., Geologic evolution of Arizona: Tucson, Arizona Geological Society Digest, v. 17 , p. 397-434.

Umhoefer, P.J., 1988, Stratigraphy and tectonic setting of the upper part of the Cadwallader terrane, southwestern British Columbia: Canadian Journal of Earth Sciences, v. 27, p. 702-711.

Umhoefer, P.J., and Miller, R.B., 1996, Mid-Cretaceous thrusting in the southern Coast belt, British Columbia and Washington, after strike-slip fault reconstruction: Tectonics, v. 15 , p. 545-565.

Varsek, J.L., Cook, F.A., Clowes, R.M., Journeay, J.M., Monger, J.W.H., Parrish, R.R., Kanasewich, E.R., and Spencer, C.S., 1993, Lithoprobe crustal reflection structure of the southern Canadian Cordillera 2: Coast Mountains transect: Tectonics, v. 12, p. 334-360.

Walawender, M.J., Gastil, R.G., Clinkenbeard, J.P., McCormick, W.V., Eastman, B.G., Wernicke, R.S., Wardlaw, M.S., Gunn, S.H., and Smith, B.M., 1990, Origin and evolution of the zoned La Posta-type plutons, eastern Peninsular Ranges batholith, southern and Baja California, in Anderson, J.L., ed., The Nature and origin of Cordilleran magmatism: Geological Society of America Memoir 174, p. 1-18.

Williams, I.S., 1998, U-Th-Pb geochronology by ion mi- croprobe, in McKibben, M.A., and Shanks, W.C., III, eds., Applications of microanalytical techniques to understanding mineralizing processes: Reviews in Economic Geology, p. 1-35.

Wooden, J.L., and Miller, D.M., 1990, Chronologic and isotopic framework for Early Proterozoic crustal evolution in the eastern Mojave Desert region, SE California: Journal of Geophysical Research, v. 95, p. $20,133-20,146$.

Woodsworth, G.J., Anderson, R.G., Armstrong, R.L. Struik, L.C., Van der Heyden, P., and Yorath, C.J., 1992, Plutonic regimes, in Gabrielse, H., ed., Geology of the Cordilleran orogen in Canada: Ottawa, Geological Survey of Canada, p. 493-531.

Wynne, P.J., Irving, E., Maxson, J.A., and Kleinspehn, K.L., 1995, Paleomagnetism of the Upper Cretaceous strata of Mount Tatlow: Evidence for $3000 \mathrm{~km}$ of northward displacement of the eastern Coast belt, British Columbia: Journal of Geophysical Research, v. 100 , p. 6073-6091.

Manuscript Received by the Society 29 September 2002 REVISED MANuscript Received 28 January 2003 MANUSCRIPT ACCEPTED 5 FEBRUARY 2003

Printed in the USA 